\title{
STATEMENT ON SEASONAL INFLUENZA VACCINE FOR 2012-2013
}

\section{Preamble}

The National Advisory Committee on Immunization (NACl) provides the Public Health Agency of Canada with ongoing and timely medical, scientific and public health advice relating to immunization. The Public Health Agency of Canada acknowledges that the advice and recommendations set out in this statement are based upon the best currently available scientific knowledge and is disseminating this document for information purposes. People administering the vaccine should also be aware of the contents of the relevant product monograph(s). NACl recommendations for use and other information set out herein may differ from that set out in the product monograph(s). Manufacturer(s) have sought approval of the vaccine(s) and provided evidence as to its safety and efficacy only when it is used in accordance with the product monographs. $\mathrm{NACl}$ members and liaison members conduct themselves within the context of the Public Health Agency of Canada's Policy on Conflict of Interest, including yearly declaration of potential conflict of interest.

\section{IMPORTANT note regarding antiviral guidelines:}

Antiviral recommendations are no longer under the purview of $\mathrm{NACl}$. Guidance for the practitioner on the use of antiviral medication has been developed by the Association of Medical Microbiology and Infectious Disease Canada (AMMI Canada) and can be accessed at: http://www.ammi.ca/guidelines.

\footnotetext{
† NACI Members: Dr. Bryna Warshawsky (Chair), Dr. Natasha Crowcroft, Ms. Anita Hanrahan, Dr. Bonnie Henry, Dr. Shainoor Ismail (Executive Secretary), Dr. Deepali Kumar, Dr. Shelly McNeil, Dr. Caroline Quach-Thanh, Dr. Marina Salvadori, Dr. Blair Seifert, Dr. Nadine Sicard, Dr. Wendy Vaudry, Dr. Richard Warrington

Liaison Representatives: Dr. Jason Brophy (Canadian Association for Immunization Research and Evaluation), Dr. Ian Gemmill (Canadian Public Health Association), Dr. Alison Mawle (U.S. Centers for Disease Control and Prevention), Dr. Dorothy Moore (Canadian Paediatric Society), Dr. Heather Morrison, (Council of Chief Medical Officers of Health), Dr. Anne Opavsky (Association of Medical Microbiology and Infectious Disease Canada), Dr. Pierre Plourde (Committee to Advise on Tropical Medicine and Travel), Dr. Shelley Rechner (College of Family Physicians of Canada), Dr. Vyta Senikas (Society of Obstetricians and Gynaecologists of Canada).

Ex-Officio Representatives: Lt.-Col. Dr. Jim Anderson (Canadian Forces Health Services Group, Department of National Defence), Dr. Agnes Klein (Biologics and Genetic Therapies Directorate, Health Canada), Dr. Barbara Law (Centre for Immunization and Respiratory Infectious Diseases, Public Health Agency of Canada), Dr. Marcus Lem (First Nations and Inuit Health Branch, Health Canada), Ms. Danielle Poulin (Centre for Immunization and Respiratory Infectious Diseases, Health Canada), Dr. Joanne Xiong (Biologics and Genetic Therapies Directorate, Health Canada).

Additional Influenza Working Group Members: Dr. Brenda Cholin, Dr. Curtis Cooper, Dr. Scott Halperin, Dr. Joanne Langley, Dr. Allison McGeer, and Dr. Paul Van Buynder.
} 


\section{Table of Contents}

Summary Table of Information Contained in this NACl Statement
I. Introduction
II. Methods
III. Epidemiology
IV. Seasonal Influenza Vaccine
V. Recommendations
VI. Immunization of Health Care Workers

Tables

List of Abbreviations

References

Appendix I: New Evidence Review for Children 24-59 Months of Age 


\section{Summary of Information Contained in this NACI Statement}

The following table highlights key information for immunization providers. Please refer to the remainder of the statement for details.

\section{TABLE 1: Summary of information contained in this NACI Statement}

\begin{tabular}{|c|c|}
\hline 1. WHAT & $\begin{array}{l}\text { What is influenza? } \\
\text { Influenza is a respiratory infection caused by influenza A and B viruses. In Canada it generally occurs each year in the late } \\
\text { fall and winter months. Symptoms typically include the sudden onset of headache, chills, cough, fever, loss of appetite, } \\
\text { muscle aches and fatigue, running nose, sneezing, watery eyes and throat irritation. Nausea, vomiting and diarrhea may } \\
\text { also occur, especially in children. } \\
\text { Most people will recover within a week or ten days, but some - including those } 65 \text { years of age and older and adults } \\
\text { and children with chronic conditions - are at greater risk of more severe complications, such as pneumonia. Additional } \\
\text { information about influenza is available on the Publich Health Agency of Canada web site. }\end{array}$ \\
\hline & 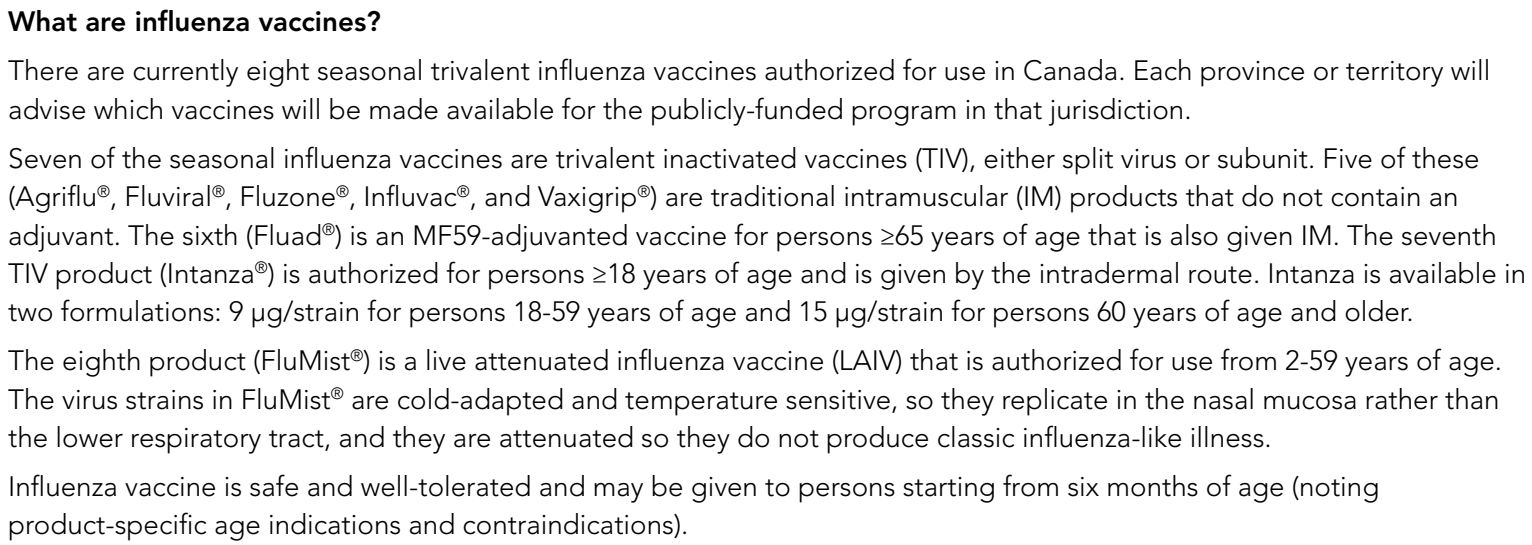 \\
\hline 2. WHO & $\begin{array}{l}\text { Who to immunize? } \\
\text { Immunization programs should focus on: } \\
\text { - those at high risk of influenza-related complications - adults and children with underlying health conditions, including } \\
\text { morbid obesity; residents of nursing homes and other chronic care facilities; people } \geq 65 \text { years of age; children } 6 \text { to } \\
59 \text { months of age; pregnant women; and Aboriginal peoples; } \\
\text { - those capable of spreading influenza to individuals at high risk of complications - health care providers in facilities and } \\
\text { community settings; household contacts of high-risk persons including infants < } 6 \text { months of age; those providing care to } \\
\text { children } \leq 59 \text { months of age; and those providing services in closed settings to those at high risk (e.g. crew on a ship); and } \\
\text { - those who provide essential community services. } \\
\text { NACl also encourages influenza vaccine for all Canadians, because significant illness and societal costs also occur in people } \\
\text { not considered to be at high risk of complications. }\end{array}$ \\
\hline
\end{tabular}




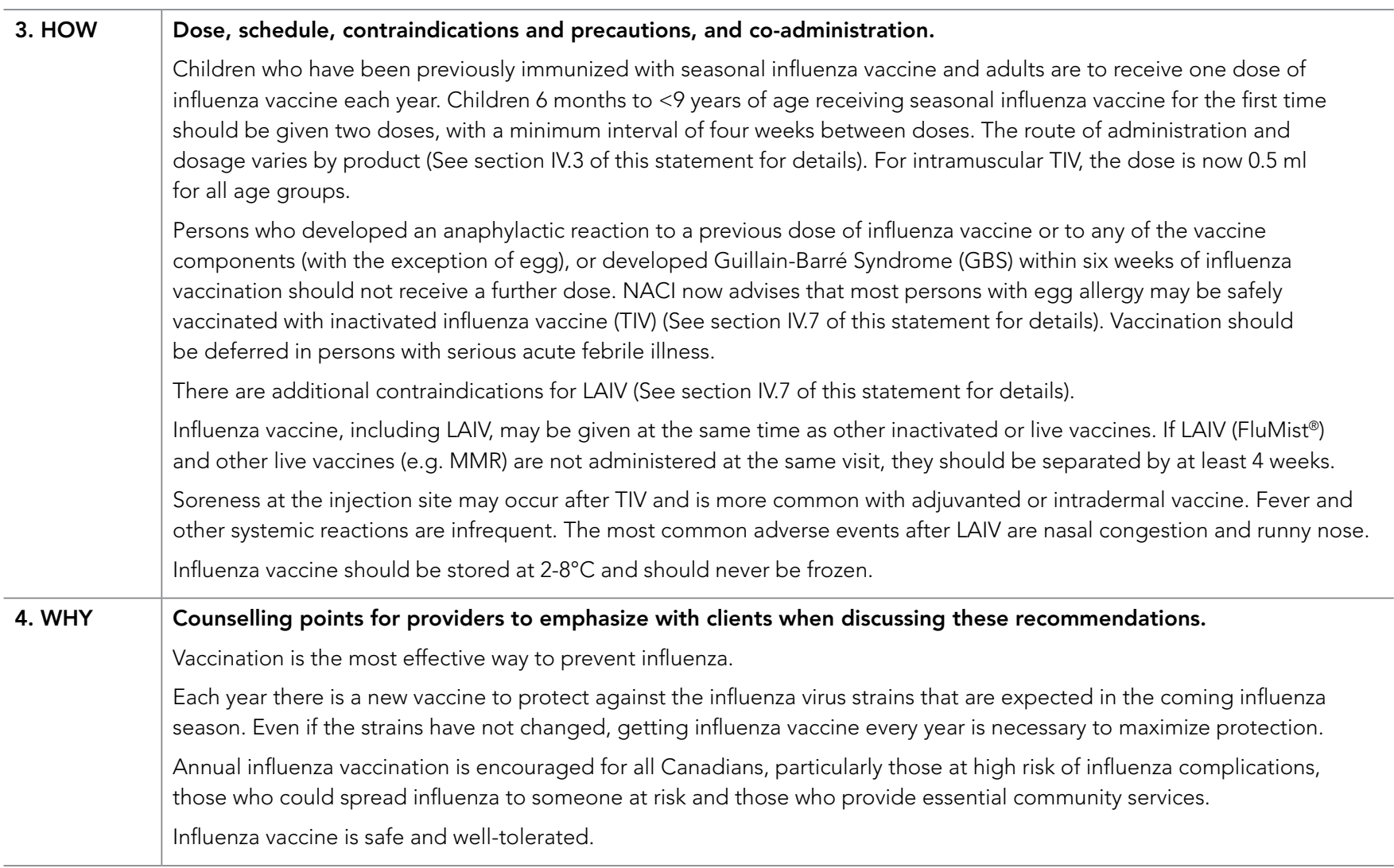




\section{Introduction}

\section{I.1 OVERVIEW AND SUMMARY OF CHANGES}

The purpose of this statement is to provide the $\mathrm{NACl}$ recommendations for immunization with seasonal influenza vaccine for the 2012-2013 season.

The seasonal trivalent vaccine for 2012-2013, as per recommendations by the World Health Organization for the northern hemisphere, contains:

- A/California/7/2009 (H1N1)pdm09-like virus;

- A/Victoria/361/2011 (H3N2)-like virus; and

- $B /$ Wisconsin/1/2010-like virus (B Yamagata lineage).

The 2012-2013 statement contains updated information from the 2011-2012 influenza season and product information for all eight influenza vaccines authorized for use in Canada, including Influvac ${ }^{\circledR}$, Fluviral $^{\circledR}$, Vaxigrip ${ }^{\circledR}$, Intanza ${ }^{\circledR}$, FluMist $^{\circledR}$, Agriflu $^{\circledR}$, Fluad $^{\circledR}$, and Fluzone ${ }^{\circledR}$ (see Table 2 for product characteristics).

There have been two changes in the recommended recipients for influenza vaccine since the Statement on Seasonal Influenza Vaccine for 2011-2012. NACI has now included children 24 to 59 months of age among recommended recipients of seasonal influenza vaccine. This means that ALL children 6 to 59 months of age, regardless of chronic conditions, are recommended recipients of seasonal influenza vaccination. Accordingly, individuals providing regular child care to children 6 to 59 months of age, whether in or out of the home, are also recommended recipients of seasonal influenza vaccination.

Immunization programs should continue to focus on those persons at high risk of influenza-related complications, those capable of transmitting influenza to individuals at high risk of complications and those who provide essential community services (See Section V.2 and Table 4 for full details). Full details, including recommendations for persons with immune compromising and other chronic health conditions, can be found in the remainder of the 2012-2013 statement.
In the 2012-2013 statement, NACI recommends avoiding re-vaccination if Guillian Barré Syndrome developed within six weeks after a previous influenza immunization. This was changed from eight weeks in the Statement on Seasonal Influenza Vaccines for 2011-2012.

The section "Strategies for Reducing the Impact of Influenza" has been removed and can be found in the Statement on Seasonal Influenza Vaccines for 2011-2012 at http://www.phac-aspc.gc.ca/publicat/ccdr-rmtc/11vol37/ acs-dcc-5/index-eng.php.

\section{I.2 BACKGROUND}

Influenza A viruses are classified into subtypes on the basis of two surface proteins: haemagglutinin (HA) and neuraminidase (NA). Three subtypes of haemagglutinin $(\mathrm{H} 1, \mathrm{H} 2$ and $\mathrm{H} 3)$ and two subtypes of neuraminidase (N1 and N2) are recognized among influenza $A$ viruses that have caused widespread human disease. Immunity to the $\mathrm{HA}$ and NA proteins reduces the likelihood of infection and lessens the severity of disease if infection occurs.

Influenza B viruses have evolved into two antigenically distinct lineages since the mid-1980s, represented by B/ Yamagata/16/88-like and B/Victoria/2/87-like viruses. Viruses from both the B/Yamagata and B/Victoria lineages contribute variably to influenza illness each year.

Over time, antigenic variation (antigenic drift) of strains occurs within an influenza A subtype or B lineage. Antigenic drift, which may occur in one or more influenza vaccine components, generally requires seasonal influenza vaccines to be reformulated annually. Seasonal influenza vaccines contain standardized amounts of the HA protein from representative seed strains of the two human influenza A subtypes (H3N2 and $\mathrm{H} 1 \mathrm{~N} 1)$ and one of the two influenza B lineages (Yamagata or Victoria). HA-based serum antibody produced to one influenza A subtype is anticipated to provide little or no protection against strains belonging to the other subtype. The potential for vaccine to stimulate antibody protection across $B$ lineages requires further evaluation and may be dependent upon age and/or prior antigenic experience with both $B$ lineages. ${ }^{(1)-(5)}$ 


\section{Methods}

Details regarding NACl's evidence-based process for developing a statement are outlined in Evidence-Based Recommendations for Immunization: Methods of the NACl, January 2009, CCDR, available at http://www. phac-aspc.gc.ca/publicat/ccdr-rmtc/09vol35/acs-1/ index-eng.php.

Annual influenza vaccine recommendations are developed by the Influenza Working Group (IWG) for consideration by $\mathrm{NACl}$. Recommendation development includes review of a variety of issues including the burden of influenza illness and the target populations for vaccination; safety, immunogenicity, efficacy, and effectiveness of influenza vaccines; vaccine schedules; as well as other aspects of influenza immunization.

To develop the 2012-2013 statement the IWG and NACI identified key questions which guided specific literature

\section{Epidemiology}

\section{III.1 DISEASE DESCRIPTION}

It is estimated that between 10 to $20 \%$ of the population becomes infected with influenza each year ${ }^{(6)}$ with an annual global attack rate estimated at $5-10 \%$ in adults and $20-30 \%$ in children. ${ }^{(7)}$ Rates of influenza infection are highest in children, but rates of serious illness and death are highest in older persons ( $>65$ years) and persons with underlying medical conditions. ${ }^{(8)}$ Influenza infection is most commonly associated with febrile upper and lower respiratory tract infection. Complications such as secondary bacterial pneumonia and worsening of pre-existing medical conditions can cause serious illness. Influenza testing is not routinely sought, or may be sought too late for laboratory confirmation, which makes it difficult to assess the true burden of influenza in terms of incidence, deaths and hospitalizations. It is estimated, however, that in a given year up to 20,000 hospitalizations related to influenza may occur ${ }^{(9)(10)}$; that as many as 4,000 Canadians, mostly seniors, may die from pneumonia related to influenza; and that others may die from other serious complications of influenza. ${ }^{(11)}$ reviews and syntheses, including the review of evidence for children 24 to 59 months of age. Following critical appraisal of individual studies and the development of summary tables with ratings of the quality of the evidence, proposed recommendations for influenza vaccine use were developed. The epidemiological analysis of the 2011-2012 influenza season was prepared by the Centre for Immunization and Respiratory Infectious Diseases of the Public Health Agency of Canada (PHAC).

The evidence and proposed recommendations were presented to $\mathrm{NACl}$ on May 1, 2012. Following thorough review of the evidence, the committee voted on specific recommendations. The description of relevant considerations, rationale for specific decisions, and knowledge gaps are described in the text. PHAC maintains documentation of these processes throughout knowledge synthesis and recommendation development.

\section{III.2 NATIONAL INFLUENZA SURVEILLANCE IN THE 2011-2012 SEASON}

\section{III.2.1 Disease Distribution}

National influenza surveillance is coordinated through the Centre for Immunization and Respiratory Infectious Diseases (CIRID), PHAC. The FluWatch program collects data and information from various sources to provide a national picture of influenza activity. Detailed methodology for FluWatch has been described previously. ${ }^{(12)}$

The information in this statement for the 2011-2012 season is based on surveillance data from 28 August 2011 to 28 April 2012, unless otherwise specified. Data are preliminary and numbers may fluctuate because of delayed reporting. For more current information, readers should refer to the FluWatch reports available at: http://www.phac-aspc.gc.ca/ fluwatch/aiisr-raisi-eng.php.

Influenza activity in Canada remained low from September 2011 to early-February 2012, with only a few regions reporting increased influenza activity, the western provinces and Ontario and Quebec. Influenza activity continued to increase throughout the month of February and March in most regions across Canada with peak activity having occurred around mid-March. By late 
March 2012, overall influenza activity started to decline. Influenza activity remained elevated in some regions (i.e. in Ontario, Quebec, the Prairies and the Atlantic Region) at the end of April 2012. Since the start of the season, 459 outbreaks of influenza or influenza-like illness (ILI) have been reported of which the majority were in longterm care facilities (55\%).

From the start of the season until the beginning of March 2012, influenza A detections predominated. Since March 2012, however, influenza B virus detections predominated. As of 28 April 2012, 47.8\% $(5,153 / 10,773)$ of the influenza detections were for influenza $A$ viruses (of which $40.6 \%$ were $A(H 3) ; 19.0 \%$ were $A(H 1 N 1) p d m 09$; and $40.4 \%$ were unsubtyped) and $52.2 \%$ were for influenza B viruses.

Detailed information on age and influenza type and sub-type were received on $84 \%(9,047)$ of the 10,773 reported laboratory confirmed cases. The proportions of cases by age group are as follows: $21.2 \%$ were $<5$ years; $17.9 \%$ were between $5-19$ years; $22.2 \%$ were between $20-44$ years; $15.3 \%$ were between $45-64$ years of age; $23.1 \%$ were $>=65$ years; and $0.2 \%$ with age unknown. Of the 792 influenza $A(\mathrm{H} 1 \mathrm{~N} 1)$ pdm09 cases, the largest proportions were between $20-44$ years of age (34\%) and $<5$ years of age (26\%). Of the 2,008 influenza $A(H 3 N 2)$ cases, the largest proportions were in those $>=65$ years (34\%) and between 20-44 years of age (22\%). Of the 4,430 influenza B cases, the largest proportions were in those between 5-19 years of age $(25 \%),>=65$ years $(22 \%)$ and $<5$ years of age $(22 \%)$.

From 1 September 2011 to 3 May 2012, the National Microbiology Laboratory (NML) antigenically characterized 1,010 influenza viruses (196 A/H3N2, $182 \mathrm{~A} / \mathrm{H} 1 \mathrm{~N} 1$ and 632 B). Of the $196 \mathrm{~A} / \mathrm{H} 3 \mathrm{~N} 2$ viruses tested, $90.3 \%$ (177) were antigenically related to the $2011-2012 \mathrm{H} 3 \mathrm{~N} 2$ vaccine strain A/Perth/16/2009 while $9.7 \%$ (19) showed reduced titer with antiserum produced against A/Perth/16/2009. Of the $182 \mathrm{~A} /$ $\mathrm{H} 1 \mathrm{~N} 1$ viruses tested, $97.3 \%$ (177) were antigenically related to the 2011-2012 H1N1 vaccine strain A/California/07/2009 while $2.7 \%$ (5) showed reduced titer with antiserum produced against A/California/07/2009. Of the 632 influenza $B$ viruses characterized, $49.8 \%$ (315) were antigenically related to the 2011-2012 vaccine strain B/Brisbane/60/2008 (Victoria lineage); one of the $315 \mathrm{~B}$ viruses showed reduced titer with antiserum produced against B/Brisbane/60/2008. The other $50.2 \%$ (317) of the B viruses were antigenically related to the reference virus B/Wisconsin/01/2010-like, which belongs to the Yamagata lineage.

\section{III.2.2 Severe IIIness Surveillance}

\section{Paediatric hospitalizations and deaths}

From 1 September 2011 to 28 April 2012, preliminary data show 524 cases of influenza-associated paediatric (16 years of age and under) hospitalizations were reported through the Immunization Monitoring Program Active (IMPACT) network. Of those, $44 \%$ (230) were due to influenza $A$ and $56 \%$ (294) were due to influenza B. The proportion of cases by age group were as follows: $15 \%$ were infants $<6$ months of age; $20 \%$ were children $6-24$ months of age; $31 \%$ were between $2-4$ years; $23 \%$ were between $5-9$ years; and $10 \%$ were between $10-16$ years. Five influenza-associated paediatric deaths have been reported to date this season from IMPACT hospitals and all were associated with influenza B infection.

Additional preliminary information was available for $58 \%$ (264/453) of the pediatric hospitalized cases identified between the start of the season until 7 April, 2012. Approximately $46 \%$ (122/264) of the paediatric cases had an underlying health condition. Immunization history was obtained for $79 \%$ (208) of the 264 cases; of those, $12 \%$ (25/208) were immunized for influenza in the 2011-2012 season. Approximately 9\% (24/264) of the paediatric cases required intensive care treatment. The most common clinical manifestations reported among the 264 cases were: fever (94\%), cough (87\%), coryza (65\%), lethargy (55\%), and respiratory distress (41\%).

\section{Adult hospitalizations and deaths}

Influenza-associated adult hospitalizations are reported to PHAC by the majority of provinces and territories in Canada except for British Columbia, Quebec, and New Brunswick and only hospitalizations that require intensive medical care are reported by Saskatchewan. From 1 September 2011 to 28 April 2012, 858 influenza-associated adult (20 years of age and over) hospitalizations have been reported. The proportion of cases by age group is as follows: $18 \%$ were in those $20-44$ years of age; $27 \%$ were in those $45-64$ years of age and $55 \%$ were in those $\geq 65$ years. There were 73 influenza-associated deaths in adults reported as of April 28, 2012; 78\% of which were in those $\geq 65$ years of age.

Based on information obtained through the Canadian Nosocomial Infection Surveillance Program (CNISP) during the previous 2010-2011 influenza season ( $n=831$ ), approximately $87 \%$ of the adult hospitalized cases had an underlying health condition. Immunization information was obtained from $38 \%$ (317/831) of the cases; of those, $43 \%$ 
(137/317) received the 2010-2011 influenza vaccine. Approximately $14 \%$ of the adult cases during the $2010-2011$ season required intensive care treatment. Among the 831 adult cases, 41 deaths were reported, the majority (71\%) of which were in those $\geq 65$ years of age.

\section{III.3 INTERNATIONAL INFLUENZA SURVEILLANCE}

Between September 2011 and January 2012, influenza activity was reported in Africa, the Americas, Asia, Europe and Oceania. Influenza $A(H 3 N 2)$ viruses were predominant in Europe, in many countries in the Americas and northern Africa, and some countries in Asia. Influenza A (H1N1) pdm09 viruses circulated at very low levels in general with the exception of some countries in Asia and the Americas (including Mexico). Influenza B viruses circulated in many parts of the world and predominated in some countries (including China). ${ }^{(13)}$

While most of the viruses characterized early in the 2011-2012 season were antigenically related to virus vaccines in the 2011-2012 trivalent vaccine, there was evidence of increasing antigenic and genetic drift in the more recently circulating influenza $A(H 3 N 2)$ viruses and the proportion of influenza $B$ viruses that were from the Yamagata lineage had been increasing relative to those from the Victoria lineage. The WHO therefore recommended a change in the composition of the next northern hemisphere vaccine formulation for the 2012-2013 influenza season to include an A/Victoria/361/2011 (H3N2)-like virus and a B/Wisconsin/1/2010-like virus of the Yamagata lineage, and to continue the inclusion of an A/California/7/2009 (H1N1)pdm09-like virus. ${ }^{(13)}$

\section{III.3.1 Novel Human Influenza Viruses (Avian and Swine origin)}

\section{Human Avian Influenza H5N1}

Currently, the avian influenza H5N1 virus continues to circulate in poultry in some countries, especially in Asia. From 1 September 2011 to 2 May 2012, the WHO reported 38 cases of human A/H5N1 avian influenza infection from six countries: Indonesia $(n=11)$, Egypt $(n=16)$, Cambodia $(n=2)$, Viet Nam $(n=4)$, China $(n=2)$ and Bangladesh $(n=3)$.
Of the 38 cases, $61 \%$ (23) were in adults ( $\geq 18$ years) and $39 \%$ (15) were in children. Of the 38 cases, 84\% (32) required hospitalization; $63 \%$ died $(n=24 ; 15$ deaths were in adults and 9 were in children). Of the 38 cases, 50\% (19) had exposure to sick or dead birds while an additional $39 \%$ (15) had exposure to birds (i.e. exposed to backyard poultry; involved in the sale or slaughter of poultry or waterfowl). This avian influenza $\mathrm{H} 5 \mathrm{~N} 1$ virus continues to cause sporadic human infections with some instances of limited human-to-human transmission among very close contacts. There has been no sustained human-to-human or community-level transmission identified thus far. ${ }^{(14)}$

\section{Swine Origin Influenza Virus in Humans}

Swine influenza viruses do not normally infect humans; however, sporadic human infections with influenza viruses that normally infect swine have occurred. In the United States, from December 2005 until April 13, 2012, there have been 36 cases ( 27 were in children $\leq 18$ years of age and 9 were in adults) of human infection with swine-origin variant viruses reported. All 36 cases have recovered from their illness. Direct or indirect exposure to swine prior to illness onset was identified in the majority of cases (72\%). ${ }^{(15)}$

Of the 13 cases of $\mathrm{H} 3 \mathrm{~N} 2$ variant ( $\mathrm{H} 3 \mathrm{~N} 2 \mathrm{v}$ ) viruses containing the 2009 H1N1 M gene reported since July 2011, more than half have involved exposure to swine. Limited humanto-human transmission with the H3N2v type of virus is suspected to have occurred in cases from lowa and West Virginia in November 2011. ${ }^{(16)}$

\section{III.4 ANTIVIRAL RESISTANCE}

Details of antiviral resistance patterns of circulating influenza strains performed by the routine surveillance program at the NML are reported by the FluWatch program. From 1 September 2011 to 3 May 2012, the NML tested 990 influenza viruses for resistance to oseltamivir (by phenotypic assay and/or sequencing) and 989 influenza viruses for resistance to zanamivir (by phenotypic assay) and it was found that all viruses tested were susceptible to oseltamivir and zanamivir. A total of 591 influenza A viruses (328 H3N2 and 263 H1N1) were tested for amantadine resistance; all but one influenza $A(H 3 N 2)$ virus tested were resistant. 


\section{Seasonal Influenza Vaccine}

\section{IV.1 PREPARATIONS AUTHORIZED FOR USE IN CANADA}

\section{IV.1.1 Overview}

There are currently eight seasonal trivalent influenza vaccines authorized for use in Canada, of which seven are inactivated and one is a live attenuated vaccine:

- Agriflu $^{\circledR}$ (Novartis)

- Fluad $^{\circledR}$ (Novartis)

- FluMist ${ }^{\circledR}$ (AstraZeneca) live attenuated vaccine

- Fluviral ${ }^{\circledR}$ (GlaxoSmithKline)

- Fluzone ${ }^{\circledR}$ (Sanofi Pasteur)

- Influvac ${ }^{\circledR}$ (Abbot)

- Intanza ${ }^{\circledR}$ (Sanofi Pasteur) $9 \mu \mathrm{g}$ and $15 \mu \mathrm{g}$ formulations

- Vaxigrip ${ }^{\circledR}$ (Sanofi Pasteur)

This statement describes the use of all eight vaccines. Further detail for Intanza ${ }^{\circledR}$, FluMist ${ }^{\circledR}$, and Fluad ${ }^{\circledR}$ may be found in supplementary $\mathrm{NACl}$ statements for each product. $^{(17)-(19)}$

The antigenic characteristics of current and emerging influenza virus strains provide the basis for selecting the strains included in each year's vaccine. All manufacturers of influenza vaccines in Canada have confirmed to the Biologics and Genetic Therapies Directorate of Health Canada that the vaccines to be marketed in Canada for the 2012-2013 influenza season contain the three WHOrecommended antigenic strains for the northern hemisphere. Vaccine producers may use antigenically equivalent strains because of their growth properties.

Full details of the composition of each vaccine and a brief description of its manufacturing process can be found in the product monograph. However, key relevant details and differences between products are highlighted below and in Table 2.

All products are manufactured by a process involving chicken eggs, which may result in the vaccine containing trace amounts of residual egg protein. All influenza vaccines currently available in Canada are considered safe for use in persons with latex allergy.
The decision to include specific influenza vaccines as part of publicly-funded provincial/territorial programs depends on multiple factors such as cost-benefit evaluation and other programmatic and operational factors, such as shelf-life and implementation strategies. The publiclyfunded programs for 2012-2013 will make six of the eight authorized vaccines available to some extent, including:

- Fluviral ${ }^{\circledR}$ (GlaxoSmithKline)

- Vaxigrip ${ }^{\circledR}$ (Sanofi Pasteur)

- Intanza ${ }^{\circledR}$ (Sanofi Pasteur) $15 \mu \mathrm{g}$ formulation

- FluMist $^{\circledR}$ (AstraZeneca)

- Agriflu ${ }^{\circledR}$ (Novartis)

- Fluad $^{\circledR}$ (Novartis).

Not all products will be made available in all jurisdictions and availability of some products may be very limited, so please consult your province or territory for specifics on the products provided in your jurisdiction.

\section{IV.1.2 Trivalent Inactivated Influenza Vaccine (TIV)}

The seven TIV products currently authorized for use in Canada are a mix of split virus and subunit vaccines, which are standardized to contain the same haemagglutinin (HA) content. The amount of neuraminidase in the vaccines is not standardized. There are currently six TIV products authorized for IM injection, five without adjuvant and one with adjuvant. A seventh TIV product is for intradermal use only.

\section{TIV for intramuscular use without adjuvant}

The five inactivated IM influenza vaccines without adjuvant include:

- Fluviral ${ }^{\circledR}$ (GlaxoSmithKline)

- Vaxigrip ${ }^{\circledR}$ (Sanofi Pasteur)

- Fluzone ${ }^{\circledR}$ (Sanofi Pasteur)

- $\quad$ Agriflu ${ }^{\circledR}$ (Novartis)

- Influvac ${ }^{\circledR}$ (Abbott)

\section{MF59-adjuvanted TIV for intramuscular use}

Fluad $^{\circledR}$ (Novartis) contains the adjuvant MF59, which is an oil-in-water emulsion composed of squalene as the oil phase, stabilized with the surfactants polysorbate 80 and sorbitan triolate in citrate buffer. 


\section{TIV for intradermal use without adjuvant}

Intanza ${ }^{\circledR}$ (Sanofi Pasteur) for intradermal injection has two authorized formulations

- $9 \mu \mathrm{g} \mathrm{HA}$ (for each of the three strains) per $0.1 \mathrm{~mL}$ for persons 18-59 years of age, and

- $15 \mu \mathrm{g} \mathrm{HA}$ (for each of the three strains) per $0.1 \mathrm{~mL}$ for persons $\geq 60$ years of age.

\section{IV.1.3 Live Attenuated Influenza Vaccine (LAIV)}

FluMist ${ }^{\circledR}$ is a live attenuated influenza vaccine for administration by intranasal spray and is authorized for use for persons 2-59 years of age. Each $0.2 \mathrm{~mL}$ dose of FluMist ${ }^{\circledR}$ (given as $0.1 \mathrm{~mL}$ in each nostril) contains $10^{6.5-7.5}$ fluorescent focus units (FFU) of live attenuated virus reassortants of each of three strains propagated in pathogen-free eggs. The influenza strains in FluMist ${ }^{\circledR}$ are cold-adapted and temperature sensitive, so they replicate in the nasal mucosa rather than the lower respiratory tract, and they are attenuated so they do not produce classic influenzalike illness. 
Table 2: Characteristics of influenza vaccines authorized in Canada, 2012-2013

\begin{tabular}{|c|c|c|c|c|c|c|c|c|}
\hline $\begin{array}{l}\text { Manufacturer } \\
\text { and Product } \\
\text { name }\end{array}$ & $\begin{array}{l}\text { Abbott } \\
\text { Influvac }{ }^{\circledR}\end{array}$ & $\begin{array}{l}\text { GSK } \\
\text { Fluviral }^{\circledR}\end{array}$ & $\begin{array}{l}\text { Novartis } \\
\text { Agriflu }^{\circledR}\end{array}$ & $\begin{array}{l}\text { Novartis } \\
\text { Fluad }^{\circledR}\end{array}$ & $\begin{array}{l}\text { Sanofi Pasteur } \\
\text { Vaxigrip }^{\circledR}\end{array}$ & $\begin{array}{l}\text { Sanofi Pasteur } \\
\text { Fluzone }^{\circledR}\end{array}$ & $\begin{array}{l}\text { Sanofi Pasteur } \\
\text { Intanza }{ }^{\circledR}\end{array}$ & $\begin{array}{l}\text { AstraZeneca } \\
\text { FluMist }^{\circledR}\end{array}$ \\
\hline $\begin{array}{l}\text { Vaccine } \\
\text { preparations }\end{array}$ & TIV & TIV & TIV & TIV & TIV & TIV & TIV & LAIV \\
\hline Vaccine type & $\begin{array}{l}\text { Inactivated - } \\
\text { subunit }\end{array}$ & $\begin{array}{l}\text { Inactivated - } \\
\text { split virus }\end{array}$ & $\begin{array}{l}\text { Inactivated - } \\
\text { subunit }\end{array}$ & $\begin{array}{l}\text { Inactivated - } \\
\text { subunit }\end{array}$ & $\begin{array}{l}\text { Inactivated - } \\
\text { split virus }\end{array}$ & $\begin{array}{l}\text { Inactivated - } \\
\text { split virus }\end{array}$ & $\begin{array}{l}\text { Inactivated - } \\
\text { split virus }\end{array}$ & $\begin{array}{l}\text { Live } \\
\text { attenuated }\end{array}$ \\
\hline $\begin{array}{l}\text { Route of } \\
\text { administration }\end{array}$ & IM & IM & $\mathrm{IM}$ & IM & IM & IM & ID & $\begin{array}{l}\text { Intranasal } \\
\text { spray }\end{array}$ \\
\hline $\begin{array}{l}\text { Authorized } \\
\text { ages for use }\end{array}$ & $\geq 18$ years & $\geq 6$ months & $\geq 6$ months & $\geq 65$ years & $\geq 6$ months & $\geq 6$ months & $\geq 18$ years & $2-59$ years \\
\hline $\begin{array}{l}\text { Antigen } \\
\text { content (each } \\
\text { of three } \\
\text { strains) }\end{array}$ & $\begin{array}{l}15 \mu \mathrm{g} \mathrm{HA} \\
/ 0.5 \mathrm{~mL} \text { dose }\end{array}$ & $\begin{array}{l}15 \mu \mathrm{g} \mathrm{HA} \\
/ 0.5 \mathrm{~mL} \text { dose }\end{array}$ & $\begin{array}{l}15 \mu \mathrm{g} \mathrm{HA} \\
/ 0.5 \mathrm{~mL} \text { dose }\end{array}$ & $\begin{array}{l}15 \mu \mathrm{g} \mathrm{HA} \\
/ 0.5 \mathrm{~mL} \text { dose }\end{array}$ & $\begin{array}{l}15 \mu \mathrm{g} \mathrm{HA} \\
/ 0.5 \mathrm{~mL} \text { dose }\end{array}$ & $\begin{array}{l}15 \mu \mathrm{g} \mathrm{HA} \\
/ 0.5 \mathrm{~mL} \text { dose }\end{array}$ & $\begin{array}{l}9 \mu \mathrm{g} \mathrm{HA} / 0.1 \\
\mathrm{~mL}(18-59 \\
\text { years) } 15 \mu \mathrm{g} \\
\mathrm{HA} / 0.1 \mathrm{~mL} \\
\text { (60+ years) }\end{array}$ & $\begin{array}{l}10^{6.5-7.5} \\
\text { FFU of live } \\
\text { attenuated } \\
\text { reassortants } \\
10.2 \mathrm{~mL} \text { dose }\end{array}$ \\
\hline Adjuvant & No & No & No & $\begin{array}{l}\text { MF59 } \\
\text { (oil-in-water } \\
\text { emulsion) }\end{array}$ & No & No & No & No \\
\hline $\begin{array}{l}\text { Formats } \\
\text { available }\end{array}$ & $\begin{array}{l}\text { Single dose } \\
\text { pre-filled } \\
\text { syringes with } \\
\text { or without } \\
\text { a needle }\end{array}$ & $\begin{array}{l}5 \mathrm{~mL} \\
\text { multidose vial }\end{array}$ & $\begin{array}{l}\text { Single dose } \\
\text { pre-filled } \\
\text { syringes } \\
\text { without } \\
\text { a needle }\end{array}$ & $\begin{array}{l}\text { Single dose } \\
\text { pre-filled } \\
\text { syringes } \\
\text { without } \\
\text { a needle }\end{array}$ & $\begin{array}{l}5 \mathrm{~mL} \\
\text { multi-dose } \\
\text { vial, single } \\
\text { dose } \\
\text { ampoule, } \\
\text { single-dose } \\
\text { pre-filled } \\
\text { syringes with } \\
\text { or without a } \\
\text { needle }\end{array}$ & $\begin{array}{l}5 \mathrm{~mL} \\
\text { multi-dose } \\
\text { vial, single } \\
\text { dose } \\
\text { ampoule, } \\
\text { single-dose } \\
\text { pre-filled } \\
\text { syringes } \\
\text { without a } \\
\text { needle }\end{array}$ & $\begin{array}{l}\text { Single dose } \\
\text { pre-filled } \\
\text { syringes } \\
\text { with micro- } \\
\text { injection } \\
\text { system } \\
\text { Two } \\
\text { formulations } \\
\text { (as above) }\end{array}$ & $\begin{array}{l}\text { Prefilled } \\
\text { single use } \\
\text { glass sprayer }\end{array}$ \\
\hline $\begin{array}{l}\text { Post puncture } \\
\text { shelf life for } \\
\text { mutli-dose } \\
\text { vials }\end{array}$ & $n / a$ & 28 days & $\mathrm{n} / \mathrm{a}$ & $\mathrm{n} / \mathrm{a}$ & 7 days & Not reported & $\mathrm{n} / \mathrm{a}$ & $\mathrm{n} / \mathrm{a}$ \\
\hline Thimerosal & No & Yes & No & No & $\begin{array}{l}\text { Yes - } \\
\text { multi-dose } \\
\text { vials only }\end{array}$ & $\begin{array}{l}\text { Yes - } \\
\text { multi-dose } \\
\text { vials only }\end{array}$ & No & No \\
\hline $\begin{array}{l}\text { Antibiotics } \\
\text { (traces) }\end{array}$ & Gentamicin & None & $\begin{array}{l}\text { Kanamycin } \\
\text { Neomycin }\end{array}$ & $\begin{array}{l}\text { Kanamycin } \\
\text { Neomycin }\end{array}$ & Neomycin & Neomycin & Neomycin & Gentamicin \\
\hline $\begin{array}{l}\text { Other clinically } \\
\text { relevant } \\
\text { non-medicinal } \\
\text { ingredients* }\end{array}$ & $\begin{array}{l}\text { Egg protein } \\
\text { Formaldehyde } \\
\text { CTAB } \\
\text { Polysorbate } 80\end{array}$ & $\begin{array}{l}\text { Egg protein } \\
\text { Formaldehyde } \\
\text { Sodium } \\
\text { deoxycholate } \\
\text { Sucrose }\end{array}$ & $\begin{array}{l}\text { Egg protein } \\
\text { Formaldehyde } \\
\text { Polysorbate } \\
80 \\
\text { CTAB }\end{array}$ & $\begin{array}{l}\text { Egg protein } \\
\text { Formaldehyde } \\
\text { Polysorbate } \\
80 \\
\text { CTAB }\end{array}$ & $\begin{array}{l}\text { Egg protein } \\
\text { Formaldehyde } \\
\text { Triton X-100 }\end{array}$ & $\begin{array}{l}\text { Egg protein } \\
\text { Formaldehyde } \\
\text { Triton X-100 } \\
\text { Gelatin } \\
\text { Sucrose }\end{array}$ & $\begin{array}{l}\text { Egg protein } \\
\text { Formaldehyde } \\
\text { Triton X-100 }\end{array}$ & $\begin{array}{l}\text { Egg protein } \\
\text { Gelatin } \\
\text { hydrosylate } \\
\text { Sucrose } \\
\text { Arginine } \\
\text { Monosodium } \\
\text { glutamate }\end{array}$ \\
\hline
\end{tabular}

* consult product monograph for complete listing of non-medicinal ingredients and excipients ABBREVIATIONS: CTAB (Cetyltrimethyl-ammonium bromide), FFU (fluorescent focus units), GSK (GlaxoSmithKline), HA (haemagglutinin), ID (intradermal), IM (intramuscular), LAIV (live attenuated influenza vaccine), TIV (Trivalent inactivated vaccine) 


\section{IV.2 EFFICACY, EFFECTIVENESS AND IMMUNOGENICITY}

\section{IV.2.1 Efficacy and Effectiveness}

Multiple studies show that influenza vaccine is efficacious with higher efficacy demonstrated against laboratoryconfirmed influenza than clinically defined outcomes. ${ }^{(20)}$ In healthy children (equal or younger than 18 or 16 years old) a systematic review and meta-analyses showed that efficacy of influenza vaccine against laboratory confirmed influenza ranged from $59 \%$ to $82 \%$, efficacy against serologicallyconfirmed influenza ranged from 54 to $63 \%$ and efficacy against clinical illness ranged between 33 to $36 \%$. $^{(21)-(23)}$ In children, LAIV is more efficacious than TIV. Further details are available in the Flumist statement at http://www. phac-aspc.gc.ca/publicat/ccdr-rmtc/11vol37/acs-dcc-7/ index-eng.php and Appendix I of the 2012-2013 statement.

In a systematic review, for healthy adults, inactivated influenza vaccine effectiveness against influenza-like illness was 30\% (95\% Cl 17 to 41\%)(24) and efficacy against laboratory-confirmed influenza was $80 \%$ (95\% Cl 56\% to 91\%) when the vaccine strain matched the circulating strains and circulation was high. ${ }^{(24)} \mathrm{A}$ recent meta analysis identified vaccine efficacy of $50 \%$ in healthy adults (95\% Cl: $27-65)$ during select seasons of vaccine mismatch, although mismatch is a relative term and the amount of crossprotection is expected to vary. ${ }^{(25)-(27)}$

In the elderly, vaccine effectiveness is about half of that of healthy adults and varies depending on the outcome and the study population. ${ }^{(28)(29)}$ Systematic reviews have also demonstrated that influenza vaccine decreases the incidence of pneumonia, hospital admissions and deaths in the elderly, ${ }^{(29)}$ and reduces exacerbations in persons with chronic obstructive pulmonary disease. ${ }^{(30)}$ In observational studies, immunization has been shown to reduce the number of physician visits, hospitalizations and deaths in high-risk persons 18 to 64 years of age, ${ }^{(31)}$ hospitalizations for cardiac disease and stroke in the elderly, ${ }^{(32)}$ and hospitalization and deaths in persons with diabetes mellitus 18 years of age and older. ${ }^{(33)}$ Increasingly, the need for caution has been expressed in the interpretation of observational studies that use non-specific clinical outcomes and that do not take into account differences in functional status or health-related behaviours. ${ }^{(34)-(39)}$

Vaccine efficacy may be lower in certain populations (e.g., persons with immune compromising conditions, elderly persons) than in healthy adults. However, the possibility of lower efficacy should not prevent immunization in those at high risk of influenza-associated morbidity, since protection is still likely to occur.
With the exception of LAIV, there is limited efficacy information for the newer products. While brief summaries are provided below, the individual $\mathrm{NACl}$ supplemental statements for Intanza ${ }^{\circledR},{ }^{(17)}$ FluMist $^{\circledR},{ }^{(18)}$ and Fluad ${ }^{\circledR(19)}$ should be consulted for details.

\section{MF59-adjuvanted TIV}

The efficacy of Fluad ${ }^{\circledR}$ has not been directly studied, although a few observational studies suggest that it may be effective at reducing the risk of hospitalization for influenza and its complications in the elderly compared to unvaccinated individuals and those who received unadjuvanted subunit vaccine. However these studies have significant methodological limitations that make their interpretation difficult. ${ }^{(19)}$

\section{TIV for intradermal use without adjuvant}

The efficacy of Intanza ${ }^{\circledR}$ against laboratory-confirmed influenza and its serious complications has not been directly studied. ${ }^{(17)}$

\section{LAIV}

For FluMist ${ }^{\circledR}$, a number of studies (LAIV versus placebo and LAIV versus TIV) have been conducted in children and adults. ${ }^{(18)}$ LAIV showed higher efficacy in children across all age groups when compared to placebo regardless of circulating subtype and strain match. Additionally, three large studies in children 6 months to 18 years of age demonstrated superior efficacy of LAIV compared to TIV. In contrast to children, most comparative studies in persons 18 to 59 years of age have found that LAIV and TIV had similar efficacy or that TIV was more efficacious. ${ }^{(18)}$

\section{IV.2.2 Immunogenicity}

Intramuscular administration of TIV results in the production of circulating lgG antibodies to the viral haemagglutinin and neuraminidase proteins, as well as a more limited cytotoxic $\mathrm{T}$ lymphocyte response. Both humoral and cell-mediated responses are thought to play a role in immunity to influenza.

The antibody response after vaccination depends on several factors, including the age of the recipient, prior and subsequent exposure to antigens and the presence of immune compromising conditions. Humoral antibody levels, which correlate with vaccine protection, are generally achieved by two weeks after immunization; however, there may be some protection afforded before that time. 
While humoral immunity is thought to play a primary role in protection against infection, cell-mediated immunity, notably cytotoxic $T$ lymphocyte responses to internal viral components, is increasingly invoked as important in protecting against severe outcomes of influenza, particularly those associated with subtype HA variations (shift and drift). ${ }^{(40)}$

Because influenza viruses change over time, immunity conferred in one season will not reliably prevent infection by an antigenically drifted strain. For this reason, the antigenic components of the vaccine usually change each year, and annual immunization is recommended. Even if the vaccine strains have not changed, immunity generally wanes within a year of receiving the vaccine and re-immunization reinforces optimal protection for the coming influenza season.

Repeated annual administration of influenza vaccine has not been demonstrated to impair the immune response of the recipient to influenza virus.

Although the initial antibody response may be lower to some influenza vaccine components among elderly recipients, a literature review identified no evidence for subsequent antibody decline that was any more rapid in the elderly than in younger age groups. ${ }^{(41)}$

Influenza vaccination can induce protective antibody levels in a substantial proportion of adults and children with immune compromising conditions, including transplant recipients, those with proliferative diseases of the hematopoietic and lymphatic systems, and HIV-infected patients. ${ }^{(42)-(46)}$ Most studies have shown that administration of a second dose of influenza vaccine to elderly individuals or other individuals who may have an altered immune response does not result in a clinically significant antibody boost. ${ }^{(45)(47)-(50)}$

\section{MF59-adjuvanted TIV}

The mechanism of action of MF59 ${ }^{\circledR}$ is not fully determined and has primarily been studied using in vitro and mouse models. From these studies it seems that MF59 may act differently from aluminum-based adjuvants.

These studies show that MF59 ${ }^{\circledR}$ acts locally in the muscle fibres to create a local immune-stimulatory environment at the injection site. ${ }^{(51)}$ MF59 ${ }^{\circledR}$ allows for an increased influx of phagocytes (e.g., macrophages and monocytes) to the site of injection. The recruited phagocytes are further stimulated by MF59 ${ }^{\circledR}$ thereby increasing the production of chemokines to attract more innate immune cells and inducing differentiation of monocytes into dendritic cells. ${ }^{(52)(53)}$ MF59 ${ }^{\circledR}$ further facilitates the internalization of antigen by these dendritic cells. ${ }^{(53)(54)}$ The overall higher number of cells available locally increases the likelihood of interaction between an antigen presenting cell and the antigen leading to more efficient transport of antigen to the lymph nodes, with resulting improved T cell priming. ${ }^{(53)}$

\section{TIV for intradermal use without adjuvant}

The skin is a potent immune organ and contains a larger number of antigen-presenting dendritic cells than muscle. Influenza antigen administered by the intradermal route has a high likelihood of being processed by local dendritic cells. Thus, the vaccine is thought to stimulate both cell-mediated immunity and antibody production.

The intradermal product, Intanza ${ }^{\circledR}$, has been shown to elicit an immune response that is comparable to TIV, with or without adjuvant, administered by the intramuscular route, with some variation in results according to the serological method used.(17) For further details, consult the Addendum to the 2010-2011 Seasonal Trivalent Inactivated Influenza Vaccine: Recommendations on the use of intradermal trivalent inactivated influenza vaccine (TIV-ID) at http:// www.phac-aspc.gc.ca/publicat/ccdr-rmtc/11vol37/ acs-dcc-4/index-eng.php. ${ }^{(17)}$

\section{LAIV}

LAIV (FluMist ${ }^{\circledR}$ ), which is administered by the intranasal route, is thought to result in an immune response that mimics that induced by natural infection with wild-type viruses, with the development of both mucosal and systemic immunity. Local mucosal antibodies protect the upper respiratory tract and may be more important for protection than serum antibody.

Studies have demonstrated that the presence of an HAI antibody response after the administration of LAIV is predictive of protection. However, efficacy studies have shown protection in the absence of a significant antibody response. ${ }^{(18)}$ LAIV has generally been shown to be equally, if not more immunogenic, than TIV for all three strains in children and adolescents 2 to 17 years of age, whereas TIV was typically more immunogenic in adults than LAIV. Greater rates of seroconversion to LAIV occurred in baseline seronegative individuals compared to baseline seropositive individuals in both child and adult populations, because pre-existing immunity may interfere with response to a live vaccine. ${ }^{(18)}$ For further details, consult the $\mathrm{NACl}$ supplemental statement for FluMist ${ }^{\circledR}$ at http://www. phac-aspc.gc.ca/publicat/ccdr-rmtc/11vol37/acs-dcc-7/ index-eng.php. 


\section{Paediatric considerations}

The first time that children $<9$ years of age receive seasonal influenza immunization, a two-dose schedule is required to achieve protection. ${ }^{(55)-(57)}$ Several studies have looked at whether these two initial doses need to be given in the same season. ${ }^{(3)(58)(59)}$ Englund et al. ${ }^{(3)(59)}$ reported similar immunogenicity in children 6-23 months of age whether two doses were given in the same or separate seasons when there was no change, or only minor vaccine strain change, in vaccine formulation between seasons. However, seroprotection rates to the $B$ component were considerably reduced when there was a major $B$ lineage change despite priming with vaccination in the previous season. ${ }^{(2)(3)}$ Issues related to effective prime-boost when there is a major change in influenza $B$ lineage across sequential seasons requires further evaluation. ${ }^{(60)}$

A recent $R C T$ in Canada was conducted during the 2008-2009 influenza season using TIV in children 6-23 months of age. At enrollment, study participants were influenza vaccine naïve without a history of laboratory confirmed influenza. Study results suggests moderate improvement in antibody response without an increase in reactogenicity when two full doses $(0.5 \mathrm{~mL})$ versus two half doses $(0.25 \mathrm{~mL})$ of TIV are given to very young infants 6-11 months of age. ${ }^{(61)}$

Immunization with currently available influenza vaccines is not recommended for infants $<6$ months of age.

\section{IV.3 ADMINISTRATION OF INFLUENZA VACCINE: DOSAGE AND SCHEDULE}

With the variety of influenza vaccines that are now available, it is important for practitioners to note the specific differences in age indications, route of administration, dosage and schedule for the product(s) that they will be using. The recommended dosage schedule for the authorized products is presented in Table 3.
The first time children 6 months to $<9$ years of age receive seasonal influenza vaccine, whether TIV or LAIV, a two-dose schedule is required with a minimum interval of four weeks between doses. Pending further evidence, eligible children $<9$ years of age who have previously received one or more doses of seasonal influenza vaccine should receive one dose per influenza vaccination season thereafter. Because children 6 to 23 months of age are less likely to have had prior priming exposure to an influenza virus, special effort is warranted to ensure that a two-dose schedule is followed for previously unvaccinated children in this age group.

Infants and toddlers have a high burden of illness and their response to TIV is not as robust as with older children.

Published and unpublished evidence suggests moderate improvement in antibody response in infants, without an increase in reactogenicity, with the use of full vaccine doses. (62) In light of this evidence, $\mathrm{NACl}$ recommends that children 6 to 35 months of age should be given a full dose $(0.5 \mathrm{~mL})$ of TIV instead of the previously recommended half dose $(0.25 \mathrm{~mL})$. This recommendation applies whether the child is being given one dose of TIV or a two dose series. ${ }^{1}$

For influenza vaccines given by the intramuscular route, the deltoid muscle is the recommended site in adults and children $\geq 12$ months of age and the anterolateral thigh is the recommended site in infants between 6 and 12 months of age. The recommended injection site for Intanza ${ }^{\circledR}$, which is given intradermally using the supplied micro-injection device, is the deltoid region.

LAIV (FluMist ${ }^{\circledR}$ ) is intended for intranasal administration only and should not be administered by the intramuscular or intradermal route. It is supplied in a pre-filled single use sprayer containing $0.2 \mathrm{~mL}$ of vaccine. Approximately $0.1 \mathrm{~mL}$ (half) is sprayed into the first nostril with the recipient upright, then the dose divider clip is removed and the remainder of the vaccine $(0.1 \mathrm{~mL})$ is sprayed into the other nostril.

\footnotetext{
This information differs from the product monograph. As noted in the preamble of this statement, recommendations for use and other information in this statement may differ from that set out in the product monographs/leaflets of the Canadian manufacturers.
} 
TABLE 3: Influenza vaccine: Recommended dosage and route, by age, for the 2012-2013 Season

\begin{tabular}{|c|c|c|c|c|c|}
\hline \multirow[t]{2}{*}{ Age group } & \multirow{2}{*}{$\begin{array}{l}\text { TIV without } \\
\text { adjuvant }^{\dagger} \\
\text { IM }\end{array}$} & \multirow{2}{*}{$\begin{array}{l}\text { MF59 -adjuvanted } \\
\text { TIV (Fluad }{ }^{\circledR} \text { ) } \\
\text { IM }\end{array}$} & \multirow{2}{*}{$\begin{array}{l}\text { TIV for intradermal } \\
\left.\text { use (Intanza }{ }^{\circledR}\right) \\
\text { ID }\end{array}$} & \multirow{2}{*}{$\begin{array}{l}\text { LAIV } \\
\left.\text { (FluMist }^{\circledR}\right) \\
\text { IN }\end{array}$} & \multirow[t]{2}{*}{$\begin{array}{l}\text { Number of } \\
\text { doses required }\end{array}$} \\
\hline & & & & & \\
\hline 6-23 months & $0.5 \mathrm{~mL}^{2}$ & - & - & - & 1 or $2^{\star}$ \\
\hline $2-8$ years & $0.5 \mathrm{~mL}$ & - & - & $\begin{array}{l}0.2 \mathrm{~mL} \\
\text { (0.1 mL per nostril) }\end{array}$ & 1 or $2^{\star}$ \\
\hline 9-17 years & $0.5 \mathrm{~mL}$ & - & - & $\begin{array}{l}0.2 \mathrm{~mL} \\
\text { (0.1 mL per nostril) }\end{array}$ & 1 \\
\hline $18-59$ years & $0.5 \mathrm{~mL}$ & - & $0.1 \mathrm{~mL}(9 \mu \mathrm{g} / \text { strain })^{\ddagger}$ & $\begin{array}{l}0.2 \mathrm{~mL} \\
\text { (0.1 mL per nostril) }\end{array}$ & 1 \\
\hline 60-64 years & $0.5 \mathrm{~mL}$ & - & $0.1 \mathrm{~mL}(15 \mu \mathrm{g} / \mathrm{strain})$ & - & 1 \\
\hline$\geq 65$ years & $0.5 \mathrm{~mL}$ & $0.5 \mathrm{~mL}$ & $0.1 \mathrm{~mL}(15 \mu \mathrm{g} / \mathrm{strain})$ & - & 1 \\
\hline
\end{tabular}

$\mathrm{IM}=$ Intramuscular $\quad \mathrm{ID}=$ Intradermal $\quad \mathrm{IN}=$ intranasal

* Children 6 months to less than 9 years of age who have never received the seasonal influenza vaccine require two doses of influenza vaccine, with a minimum interval of four weeks between doses. Eligible children $<9$ years of age who have properly received one or more doses of seasonal influenza vaccine in the past should receive one dose per influenza vaccination season thereafter.

† Influvac ${ }^{\circledR} \geq 18$ years, Fluviral ${ }^{\circledR} \geq 6$ months, Agriflu ${ }^{\circledR} \geq 6$ months, Vaxigrip ${ }^{\circledR} \geq 6$ months and Fluzone ${ }^{\circledR} \geq 6$ months.

$\ddagger$ For adults with immune compromising conditions, the $15 \mu \mathrm{g}$ formulation should be considered to improve response.

\section{IV.3.3 Administration of influenza vaccine to egg allergic persons}

Since the 2011-12 influenza season, NACl has recommended that egg-allergic individuals may be vaccinated against influenza using TIV, without a prior influenza vaccine skin test, based on an assessment of risk for a severe allergic reaction to guide the method of vaccination. ( $\mathrm{NACl}$ recommendation Grade $\mathrm{A})^{2}$ Details of the vaccine delivery protocols are found below.

Because of the lack of data, the use of FluMist ${ }^{\circledR}$ in eggallergic persons is not recommended at this time. However, ovalbumin concentrations in FluMist ${ }^{\circledR}$ are documented to be very low and a study is currently underway to assess the use of FluMist ${ }^{\circledR}$ in egg-allergic persons. Its use will be re-evaluated when further data become available.

Although ovalbumin content in influenza vaccine manufactured in eggs may vary from year to year, between vaccine products or between lots of the same vaccine, ${ }^{(63)-(65)}$ vaccines marketed in Canada are approved under the European specification for ovalbumin content, which is currently $<1.2 \mu \mathrm{g} / \mathrm{mL}$, the level associated with low risks of adverse events. ${ }^{(66)}$

\footnotetext{
2 This information differs from the product monograph. As noted in the preamble of this statement, recommendations for use and other information in this statement may differ from that set out in the product monographs/leaflets of the Canadian manufacturers.
}

For details of the evidence and guidelines reviewed to make this recommendation, refer to the Statement on Seasonal Influenza Vaccine for 2011-2012 at http:// www.phac-aspc.gc.ca/publicat/ccdr-rmtc/11vol37/acsdcc-5/index-eng.php.

\section{IV.3.3.1 Vaccine delivery protocols for egg allergic persons}

The Canadian Society of Allergy and Clinical Immunology (CSACl) define seriousness of allergies and protocols for immunization of allergic persons. Vaccine providers administering influenza vaccines to egg allergic individuals can obtain details on the CSACl website. The CSACI defines egg allergy as immediate symptoms within 1-2 hours after exposure, such as urticaria and angioedema, respiratory, gastrointestinal or cardiovascular symptoms plus confirmatory allergy tests (skin test or egg specific $\operatorname{lgE})^{(67)}$ The risk of severe allergic reaction or anaphylaxis in egg-allergic individuals can be determined by assessing the history of reactions to egg. CSACl considers an egg-allergic individual to be at lower risk for severe allergic reactions if they have mild gastrointestinal or mild local skin reaction, can tolerate ingestion of small amounts of egg, or have a positive skin/specific lgE test to egg when exposure to egg is unknown. An egg-allergic individual is considered to be at higher risk for severe allergic reactions by $\mathrm{CSACl}$ if they have had a previous respiratory or cardiovascular reaction or generalized hives when exposed to egg, or have poorly controlled asthma. 
Two vaccine delivery protocols can be used for egg-allergic individuals, depending on their level of risk for an allergic reaction. ${ }^{(67)}$ Egg-allergic individuals at lower risk for severe allergic reaction can be vaccinated for influenza using a single vaccine dose. The two-step graded protocol is recommended for individuals who are at higher risk for severe allergic reaction. These protocols are as follows:

1. Full dose - A single vaccine dose without the use of a graded challenge. Individuals should be observed for 30 minutes following administration for symptom development.

2. Two-step graded dosing - A two-step graded process, whereby $10 \%$ of the dose is administered followed by 30 minutes of observation. If no symptoms develop, or symptoms are self-resolving, administer the remaining $90 \%$ with another 30 minute observation period. If sustained or severe reactions arise after the initial dose, the vaccine is withheld and the individual should be re-evaluated for receipt of the influenza vaccine.

Referral to a specialist with expertise in allergies may be necessary in occasional circumstances where there is strong concern about proceeding with the recommendations above and the individual is at risk of complications from influenza. If the individual is not in a high-risk group, the need for vaccination may be reassessed.

Egg-allergic children who are to get a second influenza vaccination during the same season can, if the first dose is tolerated well, be given a single dose of the same product used for the initial administration, which need not be from the same vaccine lot. A graded process is not needed for this second dose.

The vaccine provider should discuss the risks of potential reactions, including the potential risk for an anaphylactic reaction after the observation period. All egg-allergic individuals receiving the influenza vaccine should be observed post-vaccination for a recommended 30 minute time period, which may be extended (e.g., to 60 minutes) as a precautionary measure for higher risk individuals. Appropriate emergency treatment and resuscitative equipment should be immediately available to manage potential severe reactions or anaphylaxis.

Egg-allergic individuals should be reassessed each year prior to the administration of the influenza vaccine and immunized using a full dose or two-step graded process according to their risk of a severe reaction.

\section{IV.4 STORAGE REQUIREMENTS}

Influenza vaccine should be stored at $+2^{\circ} \mathrm{C}$ to $+8^{\circ} \mathrm{C}$ and should not be frozen. Refer to the individual product monographs for further details.

\section{IV.5 SIMULTANEOUS ADMINISTRATION WITH OTHER VACCINES}

Influenza vaccine, including LAIV, may be given at the same time as other inactivated or live vaccines. Three studies have evaluated the immune response and safety after concomitant administration of LAIV with MMR, (68)(69) varicella, ${ }^{(69)}$ and the oral polio virus (OPV). ${ }^{(70)}$ Seroresponse rates and GMT titres for MMR ( $\geq 96 \%)$ and varicella ( $\geq 82 \%)$ vaccines were found to be similar with concurrent administration of LAIV or placebo. The results of these studies demonstrated that LAIV can be safely administered concurrently with MMR and varicella vaccines to young children in routine clinical practice without reducing the immunogenicity or safety of any of the vaccines. If not administered during the same visit as other live virus vaccines (e.g. MMR or varicella), administration of the two live vaccines should be separated by at least four weeks. This interval is intended to reduce or eliminate interference from the vaccine given first on the vaccine given later.

When multiple injections are given at one clinic visit, it is preferable to administer them in different limbs. If this is not possible, injections given in one limb should be separated by a distance of at least $2 \mathrm{~cm}$. Different administration sets (needle and syringe) should be used for each injection.

The target groups for influenza and pneumococcal polysaccharide vaccines overlap considerably. Health care providers should take the opportunity to vaccinate eligible persons against pneumococcal disease when influenza vaccine is given, according to the Canadian Immunization Guide. ${ }^{(71)}$ 


\section{IV.6 ADVERSE EVENTS}

\section{TIV}

Inactivated influenza vaccination cannot cause influenza because the vaccine does not contain live virus. With IM products, soreness at the injection site lasting up to two days is common in adults but rarely interferes with normal activities. Healthy adults receiving TIV show no increase in the frequency of fever or other systemic symptoms compared with those receiving placebo.

TIV is safe and well tolerated in healthy children. Mild local reactions, primarily soreness at the vaccination site, occur in $\leq 7 \%$ of healthy children who are $<3$ years of age. Post-vaccination fever may be observed in $\leq 12 \%$ of immunized children 1 to 5 years of age.

The multidose formulations of inactivated influenza vaccine that are authorized for use in Canada (Fluviral ${ }^{\circledR}$, Vaxigrip ${ }^{\circledR}$, and Fluzone ${ }^{\circledR}$ ) contain minute quantities of thimerosal, which is used as a preservative. ${ }^{(72)(73)}$ Large cohort studies of health databases have demonstrated that there is no association between childhood vaccination with thimerosalcontaining vaccines and neurodevelopmental outcomes, including autistic-spectrum disorders. ${ }^{(74)}$ Despite the absence of data indicating any associated risk, influenza vaccine manufacturers in Canada are currently working towards production and marketing of thimerosal-free influenza vaccines. All single dose formulations of TIV (and LAIV) are thimerosal-free.

Oculorespiratory syndrome (ORS), defined as the onset of bilateral red eyes and/or respiratory symptoms (cough, wheeze, chest tightness, difficulty breathing, difficulty swallowing, hoarseness or sore throat) and/or facial swelling occurring within 24 hours of influenza immunization was reported following receipt of TIV during the 2000-2001 influenza season. ${ }^{(75)}$ Since this time, fewer cases have been reported. Although the pathophysiologic mechanism underlying ORS remains unknown, it is considered distinct from an IgE-mediated allergic response.

Persons who have a recurrence of ORS upon revaccination do not necessarily experience further episodes with future vaccinations. Data on clinically significant adverse events do not support the preference of one vaccine product over another when revaccinating those who have previously experienced ORS. For further details on ORS, consult the Canadian Immunization Guide and CCDR 2005 Volume 31 at http://www.phac-aspc.gc.ca/publicat/ccdr-rmtc/05vol31/ dr3121a-eng.php.
MF59-adjuvanted TIV (Fluad ${ }^{\circledR}$ ) produces local reactions (pain, erythema and induration) significantly more frequently than comparator non-adjuvanted vaccines, but they are classified as mild and transient. Systemic reactions (myalgia, headache, fatigue and malaise) are comparable

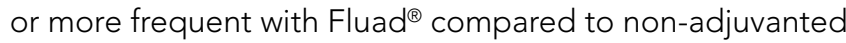
vaccines and are rated as mild to moderate and transient.

In subsequent influenza seasons, rates of local and systemic reactions are similar for Fluad $^{\circledR}$ following re-immunization. Serious adverse events are uncommon and are comparable between Fluad ${ }^{\circledR}$ and comparator vaccines. ${ }^{(19)}$

TIV given intradermally $\left(\right.$ Intanza $\left.{ }^{\circledR}\right)$ produces more frequent and more extensive erythema, swelling, induration and pruritis than vaccine given by the IM route. These reactions are generally mild and resolve spontaneously within a few days. Systemic reactions following Intanza are comparable to IM vaccine, except for myalgia which is less common with Intanza ${ }^{\circledR}$. For further details, consult the NACI Intanza addendum at http://www.phac-aspc.gc.ca/publicat/ ccdr-rmtc/11vol37/acs-dcc-4/index-eng.php. ${ }^{(17)}$

\section{LAIV}

LAIV (FluMist ${ }^{\circledR}$ ) is made from attenuated viruses that are able to replicate efficiently only at temperatures present in the nasal mucosa. The most common adverse events experienced by LAIV recipients are nasal congestion and runny nose. In a large efficacy trial, wheezing occurred in LAIV recipients at rates above those in TIV recipients only in children $<24$ months of age. ${ }^{(18)}$

Studies on FluMist ${ }^{\circledR}$ have shown that vaccine virus can be recovered by nasal swab in children and adults following vaccination (i.e. "shedding"). The frequency of shedding decreases with increasing age and time since vaccination. Shedding is generally below the levels needed to transmit infection, although in rare instances shed vaccine viruses can be transmitted from vaccine recipients to unvaccinated persons. For more detailed information on LAIV and viral shedding, the NACI FluMist supplemental statement is available at http://www.phac-aspc.gc.ca/publicat/ccdrrmtc/11vol37/acs-dcc-7/index-eng.php. ${ }^{(18)}$

\section{Other vaccine safety considerations}

Allergic responses to influenza vaccine are a rare consequence of hypersensitivity to some vaccine components. Please refer to the Canadian Immunization Guide ${ }^{(71)}$ for further details about administration of vaccine and management of adverse events including anaphylaxis. 
In a review of studies between 1976 and 2005, the United States Institute of Medicine concluded that the 1976 swine flu vaccine was associated with an elevated risk of GuillainBarré Syndrome (GBS). However, evidence was inadequate to accept or reject a causal relation between GBS in adults and seasonal influenza vaccination. ${ }^{(76)}$ More recent studies suggest that the absolute risk of GBS in the period following seasonal and $\mathrm{A}(\mathrm{H} 1 \mathrm{~N} 1)$ pdm09 influenza vaccination is about one excess case per 1 million vaccines. (77)(78) The risk of GBS associated with influenza vaccination must be balanced against the risk of GBS associated with influenza infection itself. ${ }^{(79)-(83)}$

\section{IV.7 CONTRAINDICATIONS AND PRECAUTIONS}

\section{IV.7.1 Contraindications}

Influenza vaccine should not be given to:

- people who have had an anaphylactic reaction to a previous dose; or

- people who have had an anaphylactic reaction to any of the vaccine components, with the exception of egg (See Section IV.3.3,).

For more information on vaccine safety and anaphylaxis, please see the Canadian Immunization Guide at http:// www.phac-aspc.gc.ca/publicat/cig-gci/index-eng.php.

It is not known whether influenza vaccination is causally associated with increased risk of recurrent GBS in persons with a previous history of GBS due to any cause. Avoiding subsequent influenza vaccination of persons known to have had GBS within six weeks of a previous influenza vaccination appears prudent at this time.

\section{Additional LAIV (FluMist ${ }^{\circledR}$ ) - specific contraindications}

FluMist ${ }^{\circledR}$ should not be administered to:

- Children <24 months of age due to increased risk of wheezing.

- Individuals with severe asthma (as defined as currently on oral or high dose inhaled glucocorticosteriods or active wheezing) or those with medically attended wheezing in the 7 days prior to vaccination.

- Children and adolescents (2-17 years of age) currently receiving aspirin or aspirin-containing therapy because of the association of Reye's syndrome with aspirin and wild-type influenza infection. It is recommended that aspirin-containing products in children $<18$ years of age be delayed for four weeks after receipt of FluMist ${ }^{\circledR}$.
- Pregnant women, because it is a live attenuated vaccine and there is a lack of safety data at this time. However, it is not contraindicated in nursing mothers.

- Persons with immune compromising conditions, due to underlying disease and/or therapy, as the vaccine contains live attenuated virus.

\section{IV.7.2 Precautions}

Prior to the administration of influenza vaccine, it is important to consider the following precautions including allergic reactions to previous vaccine doses, occulorespiratory syndrome (ORS), acute febrile illness, and pharmaceutical interactions.

Expert review of the risks and benefits of vaccination should be sought for those who have previously experienced severe lower respiratory symptoms (wheeze, chest tightness, difficulty breathing) within 24 hours of influenza vaccination, an apparent significant allergic reaction to the vaccine or any other symptoms (e.g., throat constriction, difficulty swallowing) that raise concern regarding the safety of re-immunization. This advice may be obtained from local medical officers of health or other experts in infectious disease, allergy/immunology and/or public health.

In view of the considerable morbidity and mortality associated with influenza, a diagnosis of influenza vaccine allergy should not be made without confirmation (which may involve skin testing) from an allergy/immunology expert. Individuals who have an allergy to substances that are not components of the influenza vaccine are not at increased risk of allergy to influenza vaccine.

Individuals who have experienced ORS - including those with a severe presentation (bilateral red eyes, cough, sore throat, hoarseness, facial swelling) but without lower respiratory tract symptoms - may be safely re-immunized with influenza vaccine. Persons who experienced ORS with lower respiratory tract symptoms should have an expert review (For more information on ORS see CCDR 2005 Volume 31 at http://www.phac-aspc.gc.ca/publicat/ ccdr-rmtc/05vol31/dr3121a-eng.php). Health care providers who are unsure whether an individual previously experienced ORS versus an IgE-mediated hypersensitivity immune response should seek advice.

Persons with serious acute febrile illness should usually not be vaccinated until their symptoms have abated. Those with mild non-serious febrile illness (such as mild upper respiratory tract infections) may be given influenza vaccine. Opportunities for immunization should not be lost because of inappropriate deferral of immunization. 
Although influenza vaccine can inhibit the clearance of warfarin and theophylline, clinical studies have not shown any adverse effects attributable to these drugs in people receiving influenza vaccine.

\section{Additional LAIV (FluMist ${ }^{\circledR}$ ) - specific precautions} FluMist ${ }^{\circledR}$ vaccine recipients should avoid close association with persons with severe immune compromising conditions (e.g., bone marrow transplant recipients requiring isolation) for at least two weeks following vaccination, because of the theoretical risk for transmission.
It is also recommended that FluMist ${ }^{\circledR}$ not be administered until 48 hours after antiviral agents active against influenza (oseltamivir and zanamivir) are stopped, and that antiviral agents not be administered until two weeks after receipt of FluMist ${ }^{\circledR}$ unless medically indicated. If antiviral agents are administered within this time frame (from 48 hours before to two weeks after FluMist ${ }^{\circledR}$ is given), revaccination should take place at least 48 hours after the antivirals are stopped.

\section{Recommendations for the 2012-2013 Seasonal Influenza Vaccine}

\section{V.1 GENERAL CONSIDERATIONS}

Health care providers may offer the seasonal vaccine when it becomes available, since seasonal influenza activity may start as early as November in the northern hemisphere. Decisions regarding the precise timing of vaccination in a given setting or geographic area should be made according to local epidemiologic factors (influenza activity, timing and intensity), opportune moments for vaccination, as well as programmatic issues. Further advice regarding the timing of influenza vaccination programs may be obtained through consultation with local public health resources. Although vaccination before the onset of the influenza season is preferred, vaccine may still be administered up until the end of the season. Health care workers (HCWs) should use every opportunity to give influenza vaccine to individuals at risk who have not been immunized during the current season, even after influenza activity has been documented in the community.

Risks and benefits of influenza vaccine should be discussed prior to vaccination, as well as the risks of not getting immunized.

\section{V.2 RECOMMENDED RECIPIENTS}

Current influenza vaccines authorized for use in Canada are immunogenic, safe and associated with minimal side effects. Influenza vaccine may be administered to anyone $\geq 6$ months of age without contraindications.

To reduce the morbidity and mortality associated with influenza, immunization programs should focus on those at high risk of influenza-related complications, those capable of transmitting influenza to individuals at high risk of complications and those who provide essential community services (see Table 4).

These groups remain the priority for influenza vaccination programs in Canada. However, significant illness and societal costs also occur with seasonal influenza in people who may not be considered at high risk of complications (i.e. healthy people aged 5 to 64 years). Therefore $\mathrm{NACl}$ also encourages influenza vaccine for all Canadians.

A full $\mathrm{NACl}$ evidence review for healthy people 5 to 64 years of age is planned and NACl's recommendations for seasonal influenza vaccine will be communicated when this review is complete. 


\section{TABLE 4: Recommended recipients of influenza vaccine for the 2012-2013 season*}

\section{People at high risk of influenza-related complications or hospitalization}

- Adults (including pregnant women) and children with the following chronic health conditions:

- cardiac or pulmonary disorders (including bronchopulmonary dysplasia, cystic fibrosis and asthma);

- diabetes mellitus and other metabolic diseases;

- cancer, immune compromising conditions (due to underlying disease and/or therapy);

- renal disease;

- anemia or hemoglobinopathy;

- conditions that compromise the management of respiratory secretions and are associated with an increased risk of aspiration;

- morbid obesity (BMI $\geq 40)$; and

- children and adolescents with conditions treated for long periods with acetylsalicylic acid.

- People of any age who are residents of nursing homes and other chronic care facilities.

- People $\geq 65$ years of age.

- All children 6 to 59 months of age. ${ }^{\dagger}$

- Healthy pregnant women (the risk of influenza-related hospitalization increases with length of gestation, i.e. it is higher in the third than in the second trimester)

- Aboriginal peoples.

\section{People capable of transmitting influenza to those at high risk}

- Health care and other care providers in facilities and community settings who, through their activities, are capable of transmitting influenza to those at high risk of influenza complications.

- Household contacts (adults and children) of individuals at high risk of influenza-related complications (whether or not the individual at high risk has been immunized):

- household contacts of individuals at high risk, as listed in the section above;

- household contacts of infants $<6$ months of age as these infants are at high risk of complications from influenza but cannot receive influenza vaccine; and

- members of a household expecting a newborn during the influenza season.

- Those providing regular child care to children $\leq 59$ months of age, whether in or out of the home. ${ }^{\dagger}$

- Those who provide services within closed or relatively closed settings to persons at high risk (e.g. crew on a ship).

\section{Others}

- People who provide essential community services.

- People in direct contact during culling operations with poultry infected with avian influenza.

* NOTE: Healthy persons aged 5 to 64 years without contraindication are also encouraged to receive influenza vaccine even if they are not in one of the priority groups.

+ NOTE: Children 24 to 59 months and their care providers have been added to the list of recommended recipients in the 2012-2013 statement. 


\section{V.2.1 People at High Risk of Influenza-Related Complications or Hospitalization}

- Adults (including pregnant women) and children with the following chronic health conditions

A number of chronic health conditions are associated with increased risk of influenza-related complications and influenza can lead to exacerbation of the chronic disease. These conditions especially include cardiac or pulmonary disorders (including bronchopulmonary dysplasia, cystic fibrosis and asthma), but also diabetes mellitus and other metabolic diseases; cancer; immune compromising conditions (due to underlying disease and/or therapy); renal disease; anemia or hemoglobinopathy; and conditions that compromise the management of respiratory secretions and are associated with an increased risk of aspiration. This category includes children and adolescents (aged 6 months to 18 years) with conditions treated for long periods with acetylsalicylic acid because of the potential increased risk of Reye's syndrome associated with influenza.

\section{- Morbid obesity}

$\mathrm{NACl}$ recognizes that information on the association between obesity and influenza-related complications continues to evolve and encourages further research. However, on the basis of data indicating an increased risk of hospitalisations and complications, from both seasonal and pandemic influenza, $\mathrm{NACl}$ recommends the inclusion of those who are morbidly obese (BMI $\geq 40$ ), with and without other chronic health conditions, among highpriority recipients of influenza vaccine. Offering vaccine to other obese adults may also be considered. $\mathrm{NACl}$ notes that it is not an expectation that a person's weight or BMI be measured in order to implement this recommendation. For details on the evidence reviewed to inform this recommendation see the Statement on Seasonal Influenza Vaccine for 2011-2012 at http://www.phac-aspc.gc.ca/ publicat/ccdr-rmtc/11vol37/acs-dcc-5/index-eng.php.

\section{- People of any age who are residents of nursing} homes and other chronic care facilities.

Such residents often have one or more chronic medical conditions and live in institutional environments that may facilitate the spread of influenza.

\section{- People $\geq 65$ years of age.}

Admissions attributable to influenza in this age group are estimated at 125 to 228 per 100000 healthy persons, ${ }^{(84)}$ and mortality rates increase with increased age. ${ }^{(11)}$

\section{- All children 6 to 59 months of age}

On the basis of existing data, $\mathrm{NACl}$ now recommends the inclusion of all children 6 to 59 months of age among high-priority recipients of influenza vaccine.

This is a revised recommendation from the 2011-2012 statement, which only included children 6 to 23 months of age. $\mathrm{NACl}$ has reviewed the burden of illness, and influenza vaccine effectiveness, efficacy, immunogenicity and safety for children 24 to 59 months of age, and now includes this age group among recommended recipients of seasonal influenza vaccine. Please note, NACl's detailed review of the literature is published as a separate appendix to this statement.

For additional details on children 6 to 23 months please see the Statement on Seasonal Influenza Vaccine for 2011-2012 at http://www.phac-aspc.gc.ca/publicat/ccdr-rmtc/11vol37/ acs-dcc-5/index-eng.php.

\section{- Pregnant women}

$\mathrm{NACl}$ recommends the inclusion of all pregnant women, at any stage of pregnancy, among high priority recipients of influenza vaccine due to the risk of influenza-associated morbidity in pregnant women, ${ }^{(85)-(89)}$ evidence of adverse neonatal outcomes associated with maternal respiratory hospitalization or influenza during pregnancy, ${ }^{\left({ }^{(90)-(93)} \text { evidence }\right.}$ that vaccination of pregnant women protects their newborns from influenza and influenza-related hospitalization, ${ }^{(94)-(97)}$ and evidence that infants born during influenza season to vaccinated women are less likely to be premature, small for gestational age, and low birth weight. ${ }^{(98)-(101)}$ Support for the hypothesis that infants are protected by transplacental antibody transfer from vaccinated mothers has recently been published. ${ }^{(102)}$ Omer et al. provides a recent review of the evidence of the benefit of maternal influenza vaccination for pregnant women and their infants. ${ }^{(103)}$

The safety of influenza vaccine during pregnancy has recently been reviewed. ${ }^{(104)}$ Active studies of influenza vaccination during pregnancy have not shown evidence of harm to the mother or fetus associated with influenza immunization. ${ }^{(105)}$ Although the cumulative sample size of active studies of influenza vaccination in pregnant women is relatively small, particularly in the first trimester, passive surveillance has not raised any safety concerns despite widespread use of influenza vaccine in pregnancy over several decades. ${ }^{(8) /(86)(104)(106)}$ Surveillance following the use of both adjuvanted and unadjuvanted $\mathrm{pH} 1 \mathrm{~N} 1$ vaccine in $>100,000$ pregnant women in Canada and >488,000 pregnant women in Europe has not revealed any safety concerns. ${ }^{(107)(108)}$ 
The antibody response to TIV in pregnant women is not expected to differ from that of non-pregnant individuals.

For further details on influenza immunization in pregnancy and other evidence reviewed to inform this recommendation, see the Statement on Seasonal Influenza Vaccine for 2011-2012 at - http://www.phac-aspc.gc.ca/publicat/ ccdr-rmtc/11vol37/acs-dcc-5/index-eng.php.

\section{- Aboriginal peoples}

Based on the body of evidence indicating a higher rate of influenza-associated hospitalization and death among Aboriginals, $\mathrm{NACl}$ recommends the inclusion of Aboriginal peoples among high-priority recipients of influenza vaccine.

Historically, Aboriginal status has been associated with increased risk of influenza-related complications including death. ${ }^{(109)(110)}$ This has also been seen with the recent 2009 H1N1 pandemic, during which Indigenous populations from Canada, Australia, New Zealand and United States (US) were reported to have hospitalisation and mortality rates three- to six-fold higher compared to the overall population. ${ }^{(111)(112)}$

It has been proposed that the increased risk of severe influenza outcomes in the Aboriginal population is a consequence of multiple factors including high prevalence of chronic health conditions (e.g., diabetes, chronic lung disease, end-stage kidney disease), ${ }^{(112)}$ obesity, delayed access to health care and increased susceptibility to disease because of poor housing and overcrowding. ${ }^{(113)-(115)}$ Research into an underlying biological mechanism for severe disease in Aboriginal peoples has generated hypotheses but is not conclusive. ${ }^{(116)(117)}$

For further details on the evidence reviewed to inform this recommendation see the Statement on Seasonal Influenza Vaccine for 2011-2012 at http://www.phac-aspc.gc.ca/ publicat/ccdr-rmtc/11vol37/acs-dcc-5/index-eng.php.

\section{V.2.2 People Capable of Transmitting Influenza to Those at High Risk of Influenza-Related Complications or Hospitalization}

People who are potentially capable of transmitting influenza to those at high risk should receive an annual vaccination, regardless of whether the high-risk person has been immunized. Immunization of care providers decreases their own risk of illness, as well as the risk of death and other serious outcomes among the patients for whom they provide care. ${ }^{(118)-(124)}$ Immunization of care providers and residents is associated with decreased risk of ILI outbreaks. (125) Individuals who are more likely to transmit influenza to those at risk of medical complications or hospitalization due to influenza include the following groups:

- Health care and other care providers in facilities and community settings.

This group includes regular visitors, emergency response workers, those who have contact with residents of continuing care facilities or residences, those who provide home care for persons in high-risk groups and students of related health care services.

- Household contacts (adults and children) of individuals at high risk of influenza complications, whether or not the individual at high risk has been immunized.

These individuals include household contacts of individuals at high risk of influenza-related complications or hospitalization, as listed earlier: household contacts of infants $<6$ months of age (who are at high risk of complications from influenza but for whom influenza vaccine is not authorized); and members of a household expecting a newborn during the influenza season.

- Those providing regular child care to children $\leq 59$ months of age whether in or out of the home.

- Those who provide services (e.g., crews on ships) within closed or relatively closed settings to persons at high risk. 


\section{V.2.3 Others}

- People who provide essential community services.

Vaccination for these individuals should be encouraged in order to minimize the disruption of services and routine activities during annual epidemics. Employers and their employees, including healthy working adults, should consider yearly influenza immunization as this has been shown to decrease work absenteeism due to respiratory and other illnesses.

- People in direct contact during culling operations involving poultry infected with avian influenza.

These individuals may be at increased risk of avian influenza infection because of exposure during the culling operation. (126)-(129) Influenza immunization on a yearly basis for these workers has been recommended in some countries ${ }^{(130)}$ and provinces, based on the theoretical rationale that it may prevent the infection of these individuals with human influenza strains and thus reduce the potential for humanavian re-assortment of genes should such workers become co-infected with avian influenza. ${ }^{(131)}$

Direct involvement may be defined as sufficient contact with infected poultry to allow transmission of avian virus to the exposed person. The relevant individuals include those performing the cull, as well as others who may be directly exposed to the avian virus, such as supervising veterinarians and inspectors. Those who are immunized with influenza vaccine just before exposure to avian influenza will not produce protective antibodies against the human vaccine strains for approximately 14 days. For further information on human health issues related to domestic avian influenza outbreaks, see the PHAC guidance at http://www.phacaspc.gc.ca/publicat/daio-enia/index.html.

\section{V.2.4 Further Comments Regarding Influenza Immunization}

- Immunization of healthy persons 5 to 64 years of age.

Individuals in this age group are encouraged to receive the vaccine, even if they are not in one of the aforementioned priority groups. For information on influenza vaccine efficacy and effectiveness see section IV.2, above.

\section{- Travellers}

All travellers are encouraged to receive influenza vaccine, even if they are not in one of the aforementioned priority groups.

Vaccine products/formulations prepared specifically for use in the Southern Hemisphere are not currently available in Canada, and the extent to which recommended vaccine components for the Southern Hemisphere may overlap with those in available Canadian formulations will vary. For further information on advising travellers about influenza prevention, consult the Committee to Advise on Tropical Medicine and Travel (CATMAT) statement at http://www.phac-aspc.gc.ca/ publicat/ccdr-rmtc/05pdf/acs-dcc3102.pdf. ${ }^{(132)}$

\section{V.3 CHOICE OF PRODUCT}

With the recent authorization of a number of new vaccines, some of which are designed to enhance immunogenicity in specific age groups, the choice of product is no longer straightforward.

Table 5 summarizes NACl's current recommendations for the choice(s) of influenza vaccine in specific age and risk groups. More details along with brief supporting rationale are outlined in the following text. 
TABLE 5: Choice of influenza vaccine for selected age and risk groups (for persons without a contraindication to the vaccine)

\begin{tabular}{|c|c|c|c|c|}
\hline $\begin{array}{l}\text { Recipient by } \\
\text { age group }\end{array}$ & $\begin{array}{l}\text { Vaccine types } \\
\text { available for use }\end{array}$ & $\begin{array}{l}\text { Preferred vaccine } \\
\text { (if any) for healthy } \\
\text { persons }\end{array}$ & $\begin{array}{l}\text { Preferred vaccine (if any) } \\
\text { for persons with chronic } \\
\text { health conditions }\end{array}$ & Comments \\
\hline $\begin{array}{l}\text { Children } 6-23 \\
\text { months of age }\end{array}$ & TIV & - & - & $\begin{array}{l}\text { Only TIV is available for } \\
\text { this age group }\end{array}$ \\
\hline $\begin{array}{l}\text { Children 2-17 } \\
\text { years } \\
\text { of age }\end{array}$ & $\begin{array}{l}\text { TIV } \\
\text { LAIV }\end{array}$ & LAIV & No preference & $\begin{array}{l}\text { Children with immune } \\
\text { compromising conditions: } \\
\text { - LAIV not recommended }\end{array}$ \\
\hline $\begin{array}{l}\text { Adults 18-59 } \\
\text { years of age }\end{array}$ & $\begin{array}{l}\text { TIV } \\
\text { TIV-ID }(9 \mu \mathrm{g}) \\
\text { LAIV }\end{array}$ & No preference & $\begin{array}{l}\text { TIV } \\
\text { TIV-ID }(9 \mu g)^{\dagger}\end{array}$ & $\begin{array}{l}\text { Adults with immune } \\
\text { compromising conditions: } \\
\text { - LAIV not recommended }\end{array}$ \\
\hline $\begin{array}{l}\text { Adults } 60-64 \\
\text { years of age }\end{array}$ & $\begin{array}{l}\text { TIV } \\
\text { TIV-ID }(15 \mu \mathrm{g}) \\
\end{array}$ & No preference & No preference & \\
\hline $\begin{array}{l}\text { Adults } 65+ \\
\text { years of age }\end{array}$ & $\begin{array}{l}\text { TIV } \\
\text { TIV-ID }(15 \mu \mathrm{g}) \\
\text { MF59- } \\
\text { adjuvanted TIV }\end{array}$ & No preference & No preference & \\
\hline Pregnant women & $\begin{array}{l}\text { TIV } \\
\text { TIV-ID }(9 \mu \mathrm{g})\end{array}$ & No preference & No preference & LAIV not recommended \\
\hline
\end{tabular}

TIV = trivalent inactivated influenza vaccine (for IM administration); TIV-ID = trivalent inactivated influenza vaccine for intradermal injection; LAIV = live attenuated influenza vaccine

† With TIV-ID, consider the $15 \mu \mathrm{g}$ formulation for adults with immune compromising conditions.

\section{Children 6 to 23 months of age}

At this time, only TIV is available for use in this age group.

\section{Children 2 to 17 years of age}

Both TIV and LAIV (FluMist ${ }^{\circledR}$ ) can be used in children between 2 and 17 years of age, with or without chronic health conditions.

Based on effectiveness, efficacy and immunogenicity data, $\mathrm{NACl}$ recommends LAIV for use in healthy children and adolescents 2-17 years of age. Available data indicate that LAIV would be preferred over TIV in this population, although $\mathrm{NACl}$ recognizes that other programmatic considerations will impact the implementation of this recommendation in publicly-funded programs. If LAIV is not available, TIV should be used as it is safe, efficacious and effective in this group.

$\mathrm{NACl}$ recommends that LAIV can be used in children 24 months and older with stable, nonsevere asthma and in children with chronic health conditions (excluding those with immune compromising conditions and severe asthma (see definition below)). Based on expert review, it is expected that LAIV should be as safe, immunogenic and efficacious in immune competent children with chronic health conditions as it is in healthy children. At this time there is insufficient evidence available to prefer LAIV over TIV in children with chronic health conditions. ${ }^{(18)}$ LAIV is not recommended for children with immune compromising conditions or those with severe asthma (as defined as currently on oral or high dose inhaled glucocorticosteriods or active wheezing) or those with medically-attended wheezing in the 7 days prior to vaccination, but can be given to children with stable, non-severe asthma.

\section{Adults 18 to 59 years of age}

There are now three types of vaccine available for use in adults 18-59 years of age: TIV, TIV given intradermally (TIV-ID) and LAIV.

For healthy adults in this age group, $\mathrm{NACl}$ considers all three types of vaccine to be acceptable choices (unless contraindicated) and does not have a preference for use. Clinical trial data have shown that TIV-ID (9 $\mathrm{gg} / \mathrm{strain})$ is statistically non-inferior to TIV (Vaxigrip ${ }^{\circledR}$ ) for all three influenza strains assessed. (17) There is some evidence that TIV may provide better efficacy than LAIV in healthy adults although not all studies are consistent on this point. ${ }^{(18)}$ 
For adults in this age group with chronic health conditions, either TIV or TIV-ID may be used. Data are limited on the use of TIV-ID in this population; however, they suggest that TIV-ID is safe and at least as immunogenic as TIV in vaccine hyporesponsive populations with chronic health conditions. ${ }^{(17)}$ If TIV-ID is being used for adults with immune compromising conditions, the $15 \mu \mathrm{g}$ formulation should be considered to improve response. At this time $\mathrm{NACl}$ concludes that there is insufficient evidence to recommend use of LAIV in adults with chronic health conditions, particularly given the evidence suggesting better immune response to TIV in this age group. ${ }^{(18)}$

LAIV is not recommended for adults with immune compromising conditions.

For information related to health care workers see section $\mathrm{VI}$, below.

\section{Adults 60 to 64 years of age}

The vaccines available for use in adults 60-64 years of age, with or without chronic health conditions, are TIV and TIV-ID (15 $\mu \mathrm{g} / \mathrm{strain})$.

$\mathrm{NACl}$ concludes that there is insufficient evidence to make a recommendation for the preferential use for either TIV or TIV-ID in this age group as there are no efficacy studies for

TIV-ID. Data from two clinical trials in adults 60 years of age and above suggest that the immune response to TIV-ID, in both healthy participants and those with chronic conditions, is statistically superior to TIV (Vaxigrip ${ }^{\circledR}$ ), although the clinical significance of differences remains uncertain. ${ }^{(17)}$ For further details, consult the NACI Intanza ${ }^{\circledR}$ addendum at http://www.phac-aspc.gc.ca/publicat/ccdr-rmtc/11vol37/ acs-dcc-4/index-eng.php.

\section{Adults $\geq \mathbf{6 5}$ years of age}

Three types of vaccine are available for use in adults $\geq 65$ years of age: TIV, TIV-ID (15 $\mathrm{g} / \mathrm{strain})$ and MF59adjuvanted TIV.
At this time, $\mathrm{NACl}$ concludes there is insufficient evidence to make a recommendation for the preferential use of any of these vaccines in adults $\geq 65$ years of age. ${ }^{(17)(19)}$

There are no published efficacy studies available for TIV-ID or MF59-adjuvanted TIV. A few observational studies suggest that Fluad $^{\circledR}$ may be effective at reducing the risk of hospitalization for influenza and its complications in the elderly compared to unvaccinated individuals and those who received unadjuvanted subunit vaccine. However these studies have significant methodological limitations that make their interpretation difficult. ${ }^{(19)}$

There is evidence from randomized controlled trials showing that Fluad $^{\circledR}$ induced higher immunogenicity and broader cross-reactivity in adults 65 years of age and older compared to the non-adjuvanted subunit vaccines, with similar but less consistent results shown in terms of improvement in antibody response relative to split-virus vaccine. ${ }^{(19)}$

The intradermal product, Intanza ${ }^{\circledR}$, has been shown to elicit an immune response that is non-inferior to TIV, with or without adjuvant, administered by the intramuscular route, with some variation in results according to the serological method used. ${ }^{(17)(133)}$

In adults 60 years of age and older, data from two clinical trials with over 4800 participants demonstrated that immune response to Intanza ${ }^{\circledR}$ was statistically superior to Vaxigrip ${ }^{\circledR}$, although differences in seroprotection rates were small. The clinical significance of these findings for both TIV-ID and MF59-adjuvanted TIV, in terms of protection against laboratory-confirmed influenza illness, is not known.

\section{Pregnant women}

Both TIV and TIV-ID $(9 \mu \mathrm{g})$ are available for use in pregnant women. $\mathrm{NACl}$ has no preference for the use of either product. Due to a lack of safety data at this time, LAIV, which is a live attenuated vaccine, should not be administered to pregnant women, but it can be administered to breastfeeding women. 


\section{Immunization of Health Care Workers}

Influenza vaccination provides benefits to health care workers (HCWs) and to the patients they care for. NACl considers the provision of influenza vaccination for HCWs who have direct patient contact to be an essential component of the standard of care for the protection of their patients. For the purposes of this document, we define a HCW as a person who provides direct patient care or indirect health services. The term "direct patient contact" is defined as activities that allow opportunities for influenza transmission between HCWs and a patient.

Transmission of influenza between infected HCWs and their vulnerable patients results in significant morbidity and mortality. Randomized controlled trials conducted in geriatric long-term care settings have demonstrated that vaccination of HCWs is associated with substantial decreases in morbidity ${ }^{(19)(122)(134)}$ and mortality ${ }^{(118)(119)(121)(122)(134)}$ in the residents. Therefore, HCWs who have direct patient contact should consider it their responsibility to be vaccinated annually for influenza.
$\mathrm{NACl}$ recommends that TIV, instead of LAIV, should be used for $\mathrm{HCW}$ s providing care to individuals with immune compromising conditions, unless the HCW will only accept LAIV. If a HCW or other person receives LAIV and is providing care to individuals with severe immune compromising conditions (defined as hospitalized and requiring care in a protected environment), they should wait two weeks following receipt of LAIV before continuing to provide care to such individuals.

HCWs who have direct patient contact should consider it their responsibility to provide the highest standard of care, which includes annual influenza vaccination. In the absence of contraindications, refusal of HCWs who have direct patient contact to be immunized against influenza implies failure in their duty of care to patients.

In order to protect vulnerable patients during influenza outbreaks, HCWs with confirmed or presumed influenza and unvaccinated HCWs who are not receiving antiviral prophylaxis should be excluded from direct patient contact. Health care organizations should have policies in place to deal with this issue. 


\section{Tables}

TABLE 6: Levels of evidence based on research design

\begin{tabular}{l|l}
\hline I & Evidence from randomized controlled trial(s). \\
\hline II-1 & Evidence from controlled trial(s) without randomization. \\
\hline II-2 & $\begin{array}{l}\text { Evidence from cohort or case-control analytic studies, preferably from more than one centre or research group using clinical } \\
\text { outcome measures of vaccine efficacy. }\end{array}$ \\
\hline II-3 & $\begin{array}{l}\text { Evidence obtained from multiple time series with or without the intervention. Dramatic results in uncontrolled experiments } \\
\text { (such as the results of the introduction of penicillin treatment in the 1940s) could also be regarded as this type of evidence. }\end{array}$ \\
\hline III & $\begin{array}{l}\text { Opinions of respected authorities, based on clinical experience, descriptive studies and case reports, or reports of } \\
\text { expert committees. }\end{array}$ \\
\hline
\end{tabular}

\section{TABLE 7: Quality (internal validity) rating of evidence}

\begin{tabular}{l|l}
\hline Good & A study (including meta-analyses or systematic reviews) that meets all design- specific criteria* well. \\
\hline Fair & $\begin{array}{l}\text { A study (including meta-analyses or systematic reviews) that does not meet (or it is not clear that it meets) at least one } \\
\text { design-specific criterion* but has no known "fatal flaw". }\end{array}$ \\
\hline Poor & $\begin{array}{l}\text { A study (including meta-analyses or systematic reviews) that has at least one design-specific* "fatal flaw", or an accumulation } \\
\text { of lesser flaws to the extent that the results of the study are not deemed able to inform recommendations. }\end{array}$ \\
\hline I & $\begin{array}{l}\text { NACl concludes that there is insufficient evidence (in either quantity and/or quality) to make a recommendation, } \\
\text { however other factors may influence decision-making. }\end{array}$ \\
\hline * General design specific criteria are outlined in Harris et al., $2001^{3}$.
\end{tabular}

\section{TABLE 8: NACI recommendation for immunization - Grades}

\begin{tabular}{|c|c|}
\hline A & $\mathrm{NACl}$ concludes that there is good evidence to recommend immunization. \\
\hline B & $\mathrm{NACl}$ concludes that there is fair evidence to recommend immunization. \\
\hline C & $\begin{array}{l}\mathrm{NACl} \text { concludes that the existing evidence is conflicting and does not allow making a recommendation for or against } \\
\text { immunization; however other factors may influence decision-making. }\end{array}$ \\
\hline D & $\mathrm{NACl}$ concludes that there is fair evidence to recommend against immunization. \\
\hline E & $\mathrm{NACl}$ concludes that there is good evidence to recommend against immunization. \\
\hline I & $\begin{array}{l}\mathrm{NACl} \text { concludes that there is insufficient evidence (in either quantity and/or quality) to make a recommendation, } \\
\text { however other factors may influence decision-making. }\end{array}$ \\
\hline
\end{tabular}

\footnotetext{
3 Harris RP, Helfand M, Woolf SH, et al. Current methods of the US Preventive Services Task Force: a review of the process. Am J Prev Med 2001;20:21-35.
} 


\section{List of Abbreviations}

\begin{tabular}{|c|c|c|c|}
\hline $\mathrm{ACIP}$ & $\begin{array}{l}\text { Advisory Committee on } \\
\text { Immunization Practices (US) }\end{array}$ & $\begin{array}{l}\text { ICD } \\
\text { ICU }\end{array}$ & $\begin{array}{l}\text { International classification of diseases } \\
\text { Intensive care unit }\end{array}$ \\
\hline $\mathrm{AE}$ & Adverse event & ID & Intradermal \\
\hline AEFI & Adverse event following immunization & $\lg E$ & Immune globulin $\mathrm{E}$ \\
\hline Al/AN & American Indian and Alaska Natives & $\lg G$ & immune globulin $\mathrm{G}$ \\
\hline AMMI & $\begin{array}{l}\text { Association of Medical Microbiology } \\
\text { and Infectious Disease }\end{array}$ & ILI & Influenza-like illness \\
\hline AOM & Acute otitis media & IM & Intramuscular \\
\hline ARI & Acute respiratory infection & IMPACT & Immunization Monitoring Program, ACTive \\
\hline BMI & Body mass index & IWG & Influenza Working Group \\
\hline ca & Cold-adapted & IQR & Interquartile range \\
\hline CADTH & $\begin{array}{l}\text { Canadian Agency for Drugs and } \\
\text { Technologies in Health }\end{array}$ & $\begin{array}{l}\text { IRR } \\
\text { LAIV }\end{array}$ & Live attenuated influenza vaccine \\
\hline CAEFISS & $\begin{array}{l}\text { Canadian Adverse Events Following } \\
\text { Immunization Surveillance System }\end{array}$ & $\begin{array}{l}\text { LOS } \\
\text { LRI }\end{array}$ & $\begin{array}{l}\text { Length of stay } \\
\text { Lower respiratory infection }\end{array}$ \\
\hline CATMAT & $\begin{array}{l}\text { Committee to Advise on Tropical } \\
\text { Medicine and Travel }\end{array}$ & $\begin{array}{l}\text { LTCF } \\
\text { MAARI }\end{array}$ & $\begin{array}{l}\text { Long-term care facility } \\
\text { Medically attended acute respiratory illness }\end{array}$ \\
\hline $\begin{array}{l}\text { CCDR } \\
\text { CDC }\end{array}$ & $\begin{array}{l}\text { Canada Communicable Disease Report } \\
\text { Centers for Disease Control and Prevention }\end{array}$ & $\begin{array}{l}\text { MAE } \\
\mathrm{mL}\end{array}$ & $\begin{array}{l}\text { Medically attended event } \\
\text { Millilitre }\end{array}$ \\
\hline $\mathrm{Cl}$ & Confidence interval & MCO & Managed care organization \\
\hline CIRID & $\begin{array}{l}\text { Centre for Immunization and Respiratory } \\
\text { Infectious Diseases }\end{array}$ & NA & Neuraminidase \\
\hline CNISP & $\begin{array}{l}\text { Canadian Nosocomial Infection } \\
\text { Surveillance Program }\end{array}$ & $\begin{array}{l}\mathrm{NACl} \\
\mathrm{NE}\end{array}$ & $\begin{array}{l}\text { National Advisory Committee on Immunization } \\
\text { Not estimated }\end{array}$ \\
\hline CSACl & $\begin{array}{l}\text { Canadian Society of Allergy } \\
\text { and Clinical Immunology }\end{array}$ & $\begin{array}{l}\text { NML } \\
\text { OME }\end{array}$ & $\begin{array}{l}\text { National Microbiology Laboratory } \\
\text { Otitis media with effusion }\end{array}$ \\
\hline ECDC & $\begin{array}{l}\text { European Centre for Disease } \\
\text { Prevention and Control }\end{array}$ & OPV & Oral poliovirus vaccine \\
\hline ECMO & Extracorporeal membrane oxygenation & ORS & $\begin{array}{l}\text { Odds ratio } \\
\text { Oculorespiratory syndrome }\end{array}$ \\
\hline FFU & Fluorescent focus units & OTC & Over the counter \\
\hline GBS & Guillain-Barré syndrome & $\begin{array}{l}\text { PCV7 } \\
\text { pH1N1 }\end{array}$ & $\begin{array}{l}\text { Heptavalent pneumococcal conjugate vaccine } \\
\text { Pandemic H1N1 } 2009\end{array}$ \\
\hline HA & Haemagglutinin & PHAC & Public Health Agency of Canada \\
\hline $\begin{array}{l}\text { HBV } \\
\text { HCW }\end{array}$ & $\begin{array}{l}\text { Hepatitis B virus } \\
\text { Health care worker }\end{array}$ & QALY & $\begin{array}{l}\text { Paediatric intensive care unit } \\
\text { Quality-adjusted life year }\end{array}$ \\
\hline HIV & Human immunodeficiency virus & $\begin{array}{l}\text { RCT } \\
\text { RE }\end{array}$ & $\begin{array}{l}\text { Randomized controlled trial } \\
\text { Reactogenicity event }\end{array}$ \\
\hline
\end{tabular}




$\begin{array}{ll}\text { RR } & \text { Relative risk } \\ \text { RSV } & \text { Respiratory syncytial virus } \\ \text { RTI } & \text { Respiratory tract infection } \\ \text { RT-PCR } & \text { Reverse transcription polymerase chain reaction } \\ \text { rRT-PCR } & \text { Real-time reverse transcription } \\ & \text { polymerase chain reaction } \\ \text { SAE } & \text { Serious adverse event } \\ \text { SD } & \text { Standard deviation } \\ \text { TESSy } & \text { The European Surveillance System } \\ \text { TIV } & \text { Trivalent inactivated influenza vaccine }\end{array}$

TIV-ID Trivalent inactivated influenza vaccine administered intradermally

$\mu$ Microgram

UIIP Universal Influenza Immunization Program (Ontario)

UK United Kingdom

URI Upper respiratory infection

US United States

VAERS Vaccine Adverse Event Reporting System (US)

VE Vaccine effectiveness

WHO World Health Organization 


\section{References}

(1) Heckler R, Baillot A, Engelmann H, et al. Crossprotection against homologous drift variants of influenza $A$ and $B$ after vaccination with split vaccine. Intervirology. 2007;50(1):58-62.

(2) Walter EB, Neuzil KM, Zhu Y, et al. Influenza vaccine immunogenicity in 6- to 23-month-old children: are identical antigens necessary for priming?. Pediatrics. 2006;118(3):e570-8.

(3) Englund JA, Walter EB, Gbadebo A, et al. Immunization with trivalent inactivated influenza vaccine in partially immunized toddlers. Pediatrics. 2006;118(3):e579-85.

(4) Levandowski RA, Regnery HL, Staton E, et al. Antibody responses to influenza $B$ viruses in immunologically unprimed children. Pediatrics. 1991;88(5):1031-6.

(5) Levandowski RA, Gross PA, Weksler M, et al. Crossreactive antibodies induced by a monovalent influenza B virus vaccine. J Clin Microbiol. 1991;29(7):1530-2.

(6) World Health Organization. Influenza. 2008; Available at: http://www.who.int/immunization/topics/ influenza/en

(7) World Health Organization. WHO position paper on influenza. Weekly Epidemiological Record. 2002(33):March 62012.

(8) Nguyen-Van-Tam J. Epidemiology of Influenza. In: Nicholson K, Webster R, Hay A, editors. Textbook of Influenza London: Blackwell Science; 1998. p. 181.

(9) Schanzer DL, Langley JM, Tam TW. Hospitalization attributable to influenza and other viral respiratory illnesses in Canadian children. Pediatr Infect Dis J. 2006;25(9):795-800.

(10) Schanzer D, Langley J, Tam T. Role of influenza and other respiratory viruses in admissions of adults to Canadian hospitals. Influenza \& Other Respiratory Viruses. 2008;2(1):1-8.

(11) Schanzer DL, Tam TW, Langley JM, et al. Influenzaattributable deaths, Canada 1990-1999. Epidemiol Infect. 2007;135(7):1109-16.

(12) Reyes F, Macey JF, Aziz S, et al. Influenza in Canada: 2005-2006 season. Can Commun Dis Rep. 2007;33(3):21-41.
(13) World Health Organization. Recommended composition of influenza virus vaccines for use in the 2012-2013 northern hemisphere influenza season. 2012; Available at: http://www.who.int/influenza/ vaccines/virus/recommendations/2012_13_north/en/ index.html.

(14) World Health Organization. Influenza at the humananimal interface (HAl). 2012; Available at: http:// www.who.int/influenza/human_animal_interface/en.

(15) Centers for Disease Control and Prevention. Reported human infections with variant influenza viruses in the United States since 2005. 2012; Available at: http:// www.cdc.gov/flu/swineflu/variant-cases-us.htm.

(16) Centers for Disease Control and Prevention. First H3N2 Variant Virus Infection Reported for 2012. 2012; Available at: http://www.cdc.gov/flu/spotlights/ h3n2v-variant-utah.htm.

(17) National Advisory Committee on Immunization. Addendum to the 2010-2011 seasonal trivalent inactivated influenza vaccine: Recommendations on the use of intradermal trivalent influenza vaccine (TIV-ID). CCDR. 2011;37(ACS-4):March 62012.

(18) National Advisory Committee on Immunization. Recommendations on the use of live, attenuated influenza vaccine (FluMist ${ }^{\circledR}$ ): Supplemental statement on seasonal influenza vaccine 2011-2012. CCDR. 2011;37(ACS-7):March 62012.

(19) National Advisory Committee on Immunization. Recommendations on the use of MF59-adjuvanted trivalent seasonal influenza vaccine $\left(\right.$ Fluad $\left.^{\circledR}\right)$ : Supplemental statement on seasonal influenza vaccine for 2011-2012. CCDR. 2011;37(ACS-6):March 62012.

(20) Langley JM, Faughnan ME, Canadian Task Force on Preventive Health,Care. Prevention of influenza in the general population: recommendation statement from the Canadian Task Force on Preventive Health Care. CMAJ. 2004;171(10):1169-70.

(21) Jefferson T, Rivetti A, Harnden A, et al. Vaccines for preventing influenza in healthy children. Cochrane Database Syst Rev. 2008(2):004879.

(22) Negri E, Colombo C, Giordano L, et al. Influenza vaccine in healthy children: a meta-analysis. Vaccine. 2005;23(22):2851-61. 
(23) Manzoli L, Schioppa F, Boccia A, et al. The efficacy of influenza vaccine for healthy children: a meta-analysis evaluating potential sources of variation in efficacy estimates including study quality. Pediatr Infect Dis J. 2007;26(2):97-106.

(24) Jefferson T, Di Pietrantonj C, Rivetti A, et al. Vaccines for preventing influenza in healthy adults. Cochrane Database Syst Rev. 2010(7):001269.

(25) Jefferson TO, Rivetti D, Di Pietrantonj C, et al. Vaccines for preventing influenza in healthy adults. Cochrane Database Syst Rev. 2007;(2)(2):CD001269.

(26) Ohmit SE, Victor JC, Rotthoff JR, et al. Prevention of antigenically drifted influenza by inactivated and live attenuated vaccines. N Engl J Med.

2006;355(24):2513-22.

(27) Herrera GA, Iwane MK, Cortese M, et al. Influenza vaccine effectiveness among 50-64-year-old persons during a season of poor antigenic match between vaccine and circulating influenza virus strains: Colorado, United States, 2003-2004. Vaccine. 2007;25(1):154-60.

(28) Govaert TM, Thijs CT, Masurel N, et al. The efficacy of influenza vaccination in elderly individuals. A randomized double-blind placebo-controlled trial. JAMA. 1994;272(21):1661-5.

(29) Rivetti $D$, Jefferson $T$, Thomas $R$, et al. Vaccines for preventing influenza in the elderly. Cochrane Database Syst Rev. 2006;3:004876.

(30) Poole PJ, Chacko E, Wood-Baker RW, et al. Influenza vaccine for patients with chronic obstructive pulmonary disease. Cochrane Database Syst Rev. 2006(1):002733.

(31) Hak E, Buskens E, van Essen GA, et al. Clinical effectiveness of influenza vaccination in persons younger than 65 years with high-risk medical conditions: the PRISMA study. Arch Intern Med. 2005;165(3):274-80.

(32) Nichol KL, Nordin J, Mullooly J, et al. Influenza vaccination and reduction in hospitalizations for cardiac disease and stroke among the elderly. N Engl J Med. 2003;348(14):1322-32.

(33) Looijmans-Van den Akker I, Verheij TJ, Buskens E, et al. Clinical effectiveness of first and repeat influenza vaccination in adult and elderly diabetic patients. Diabetes Care. 2006;29(8):1771-6.
(34) Orenstein EW, De Serres G, Haber MJ, et al. Methodologic issues regarding the use of three observational study designs to assess influenza vaccine effectiveness. Int J Epidemiol. 2007;36(3):623-31.

(35) Simonsen L. Commentary: Observational studies and the art of accurately measuring influenza vaccine benefits. Int J Epidemiol. 2007;36(3):631-2.

(36) Jackson LA, Jackson ML, Nelson JC, et al. Evidence of bias in estimates of influenza vaccine effectiveness in seniors. Int J Epidemiol. 2006;35(2):337-44.

(37) Jackson LA, Nelson JC, Benson P, et al. Functional status is a confounder of the association of influenza vaccine and risk of all cause mortality in seniors. Int J Epidemiol. 2006;35(2):345-52.

(38) Simonsen L, Taylor RJ, Viboud C, et al. Mortality benefits of influenza vaccination in elderly people: an ongoing controversy. Lancet Infect Dis. 2007;7(10):658-66.

(39) Simonsen L, Viboud C, Taylor RJ. Effectiveness of influenza vaccination. $N$ Engl J Med. 2007;357(26):2729-30.

(40) Thomas PG, Keating R, Hulse-Post DJ, et al. Cellmediated protection in influenza infection. Emerg Infect Dis. 2006;12(1):48-54.

(41) Skowronski DM, Tweed SA, De Serres G. Rapid decline of influenza vaccine-induced antibody in the elderly: is it real, or is it relevant? J Infect Dis. 2008;197(4):490-502.

(42) Anema A, Mills E, Montaner J, et al. Efficacy of influenza vaccination in HIV-positive patients: a systematic review and meta-analysis. HIV Med. 2008;9(1):57-61.

(43) Cooper C, Hutton B, Fergusson D, et al. A review of influenza vaccine immunogenicity and efficacy in HIV-infected adults. Can J Infect Dis Med Microbiol. 2008;19(6):419-23.

(44) Scharpe J, Evenepoel P, Maes B, et al. Influenza vaccination is efficacious and safe in renal transplant recipients. Am J Transplant. 2008;8(2):332-7.

(45) Manuel O, Humar A, Chen MH, et al. Immunogenicity and safety of an intradermal boosting strategy for vaccination against influenza in lung transplant recipients. Am J Transplant. 2007;7(11):2567-72. 
(46) Engelhard D, Nagler A, Hardan I, et al. Antibody response to a two-dose regimen of influenza vaccine in allogeneic T cell-depleted and autologous BMT recipients. Bone Marrow Transplant. 1993;11(1):1-5.

(47) Buxton JA, Skowronski DM, Ng H, et al. Influenza revaccination of elderly travelers: antibody response to single influenza vaccination and revaccination at 12 weeks. J Infect Dis. 2001;184(2):188-91.

(48) Ljungman P, Nahi H, Linde A. Vaccination of patients with haematological malignancies with one or two doses of influenza vaccine: a randomised study. Br J Haematol. 2005;130(1):96-8.

(49) McElhaney JE, Hooton JW, Hooton N, et al. Comparison of single versus booster dose of influenza vaccination on humoral and cellular immune responses in older adults. Vaccine. 2005;23(25):3294-300.

(50) Gross PA, Weksler ME, Quinnan GV,Jr, et al. Immunization of elderly people with two doses of influenza vaccine. J Clin Microbiol. 1987;25(9):1763-5.

(51) Mosca F, Tritto E, Muzzi A, et al. Molecular and cellular signatures of human vaccine adjuvants. Proc Natl Acad Sci U S A. 2008;105(30):10501-6.

(52) Seubert A, Monaci E, Pizza M, et al. The adjuvants aluminum hydroxide and MF59 induce monocyte and granulocyte chemoattractants and enhance monocyte differentiation toward dendritic cells. J Immunol. 2008; 180(8):5402-12.

(53) Calabro S, Tortoli M, Baudner B, et al. Vaccine adjuvants alum and MF59 induce rapid recruitment of neutrophils and monocytes that participate in antigen transport to draining lymph nodes. Vaccine. 2011;29(9):1812-23.

(54) O'Hagan D, Rappuoli R, De Gregorio E, et al. MF59 adjuvant: the best insurance against influenza strain diversity. Expert Rev Vaccines. 2011;10(4):447-62.

(55) Ritzwoller DP, Bridges CB, Shetterly S, et al. Effectiveness of the 2003-2004 influenza vaccine among children 6 months to 8 years of age, with 1 vs 2 doses. Pediatrics. 2005;116(1):153-9.

(56) Neuzil KM, Jackson LA, Nelson J, et al. Immunogenicity and reactogenicity of 1 versus 2 doses of trivalent inactivated influenza vaccine in vaccine-naive 5-8-year-old children. J Infect Dis. 2006;194(8):1032-9.
(57) Shuler CM, Iwamoto M, Bridges CB, et al. Vaccine effectiveness against medically attended, laboratoryconfirmed influenza among children aged 6 to 59 months, 2003-2004. Pediatrics. 2007;119(3):e587-95.

(58) Allison MA, Daley MF, Crane LA, et al. Influenza vaccine effectiveness in healthy 6 - to 21 -month-old children during the 2003-2004 season. J Pediatr. 2006;149(6):755-62.

(59) Englund JA, Walter EB, Fairchok MP, et al. A comparison of 2 influenza vaccine schedules in 6- to 23-month-old children. Pediatrics. 2005;115(4):1039-47.

(60) Skowronski DM, Hottes TS, De Serres G, et al. Influenza B/Victoria antigen induces strong recall of $B /$ Yamagata but lower B/Victoria response in children primed with two doses of B/Yamagata. Pediatr Infect Dis J. 2011;30(10):833-9.

(61) Skowronski DM, Hottes TS, Chong M, et al. Randomized controlled trial of dose response to influenza vaccine in children aged 6 to 23 months. Pediatrics. 2011;128(2):e276-89.

(62) Langley JM, Vanderkooi OG, Garfield HA, et al. Immunogenicity and Safety of 2 Dose Levels of a Thimersol-Free Trivalent Seasonal Influenza Vaccine in Children Aged 6-35 Months: A Randomized, Controlled Trial. J Ped Infect Dis. 2012;1(1):55-8.

(63) James JM, Zeiger RS, Lester MR, et al. Safe administration of influenza vaccine to patients with egg allergy. J Pediatr. 1998;133(5):624-8.

(64) Li JT, Rank MA, Squillace DL, et al. Ovalbumin content of influenza vaccines. J Allergy Clin Immunol. 2010;125(6):1412-3.

(65) Waibel KH, Gomez R. Ovalbumin content in 2009 to 2010 seasonal and H1N1 monovalent influenza vaccines. J Allergy Clin Immunol. 2010;125(3):749; Mar-751.

(66) Gagnon R, Primeau MN, Des Roches A, et al. Safe vaccination of patients with egg allergy with an adjuvanted pandemic H1N1 vaccine. J Allergy Clin Immunol. 2010;126(2):317-23.

(67) Canadian Society of Allergy and Clinical Immunology. Statement: administration of $\mathrm{H} 1 \mathrm{~N} 1$ and seasonal influenza vaccine to egg allergic individiuals. 2009; Available at: http:www.csaci.ca/include/files/CSACl_ H1N1_Statement.pdf. 
(68) Lum LC, Borja-Tabora CF, Breiman RF, et al. Influenza vaccine concurrently administered with a combination measles, mumps, and rubella vaccine to young children. Vaccine. 2010;28(6):1566-74.

(69) Nolan T, Bernstein DI, Block SL, et al. Safety and immunogenicity of concurrent administration of live attenuated influenza vaccine with measles-mumpsrubella and varicella vaccines to infants 12 to 15 months of age. Pediatrics. 2008;121(3):508-16.

(70) Breiman RF, Brooks WA, Goswami D, et al. A multinational, randomized, placebo-controlled trial to assess the immunogenicity, safety, and tolerability of live attenuated influenza vaccine coadministered with oral poliovirus vaccine in healthy young children. Vaccine. 2009;27(40):5472-9.

(71) National Advisory Committee on Immunization. Canadian immunization guide. 7th ed. 2006.

(72) National Advisory Committee on Immunization. Statement on thimerosal. Can Commun Dis Rep. 2003;29(ACS-1):1-12.

(73) National Advisory Committee on Immunization. Thimerosal: updated statement. An Advisory Committee Statement (ACS). Can Commun Dis Rep. 2007;33(ACS-6):1-13.

(74) Gerber JS, Offit PA. Vaccines and autism: a tale of shifting hypotheses. Clin Infect Dis. 2009;48(4):456-61.

(75) National Advisory Committee on Imunization (NACl). Supplementary statement for hte 2002-2003 influenza season: Update on oculo-respiratory syndrome in association with influenza vaccination. Can Commun Dis Rep. 2002;28(ACS-6):1-8.

(76) Institute of Medicine. Immunization safety review: Influenza vaccines and neurological complications. Washington, D.C.: Institute of Medicine of the National Academies; 2008.

(77) Juurlink DN, Stukel TA, Kwong J, et al. Guillain-Barre syndrome after influenza vaccination in adults: a population-based study. Arch Intern Med. 2006;166(20):2217-21.

(78) Prothro C, Kudish K, Fielin M, et al. Preliminary results: surveillance for Guillain-Barre syndrome after receipt of influenza A (H1N1) 2009 monovalent vaccine United States, 2009-2010. MMWR. 2010;59:657-61.
(79) Sivadon-Tardy V, Orlikowski D, Porcher R, et al. Guillain-Barre syndrome and influenza virus infection. Clin Infect Dis. 2009;48(1):48-56.

(80) Stowe J, Andrews N, Wise L, et al. Investigation of the temporal association of Guillain-Barre syndrome with influenza vaccine and influenza like illness using the United Kingdom General Practice Research Database. Am J Epidemiol. 2009;169(3):382-8.

(81) Tam CC, O’Brien SJ, Petersen I, et al. Guillain-Barre syndrome and preceding infection with campylobacter, influenza and Epstein-Barr virus in the general practice research database. PLoS ONE. 2007;2(4):e344.

(82) Grimaldi-Bensouda L, Alperovitch A, Besson G, et al. Guillain-Barre syndrome, influenzalike illnesses, and influenza vaccination during seasons with and without circulating A/H1N1 viruses. Am J Epidemiol. 2011;174(3):326-35.

(83) Andrews N, Stowe J, Al-Shahi Salman R, et al. GuillainBarre syndrome and H1N1 (2009) pandemic influenza vaccination using an ASO3 adjuvanted vaccine in the United Kingdom: self-controlled case series. Vaccine. 2011;29(45):7878-82.

(84) Simonsen L, Fukuda K, Schonberger LB, et al. The impact of influenza epidemics on hospitalizations. J Infect Dis. 2000;181(3):831-7.

(85) McNeil S, Halperin B, MacDonald N. Influenza in pregnancy: the case for prevention. Adv Exp Med Biol. 2009;634:161-83.

(86) Mak TK, Mangtani P, Leese J, et al. Influenza vaccination in pregnancy: current evidence and selected national policies. Lancet Infect Dis. 2008;8(1):44-52.

(87) Rasmussen SA, Jamieson DJ, Bresee JS. Pandemic influenza and pregnant women. Emerg Infect Dis. 2008;14(1):95-100.

(88) Siston AM, Rasmussen SA, Honein MA, et al. Pandemic 2009 influenza $A(H 1 N 1)$ virus illness among pregnant women in the United States. JAMA. 2010;303(15):1517-25.

(89) Louie JK, Acosta M, Jamieson DJ, et al. Severe 2009 $\mathrm{H} 1 \mathrm{~N} 1$ influenza in pregnant and postpartum women in California. N Engl J Med. 2010;362(1):27-35. 
(90) Goldenberg R, Culhane J, lams J, et al. Epidemiology and causes of preterm birth. Lancet.

2008;371(9606):75-84.

(91) McNeil SA, Dodds LA, Fell DB, et al. Effect of respiratory hospitalization during pregnancy on infant outcomes. Am J Obstet Gynecol. 2011;204(6 Suppl 1):S54-7.

(92) Pierce M, Kurinczuk J, Spark P, et al. Perinatal outcomes after maternal 2009/H1N1 infection: national cohort study. BMJ. 2011;342:d3214-.

(93) Centers for Disease Control and Prevention. Maternal and infant outcomes among severely ill pregnant and postpartum women with 2009 pandemic influenza A (H1N1)--United States, April 2009-August 2010. MMWR Morb Mortal Wkly Rep. 2011;60(35):1193-6.

(94) France EK, SmithRay R, McClure D, et al. Impact of maternal influenza vaccination during pregnancy on the incidence of acute respiratory illness visits among infants. Arch Pediatr Adolesc Med. 2006;160(12): 1277-83.

(95) Zaman K, Roy E, Arifeen SE, et al. Effectiveness of maternal influenza immunization in mothers and infants. N Engl J Med. 2008;359(15):1555-64.

(96) Poehling K, Szilagyi P, Staat M, et al. Impact of maternal immunization on influenza hospitalizations in infants. Obstet Gynecol. 2011;204(6 Suppl 1):S141-8.

(97) Eick AA, Uyeki TM, Klimov A, et al. Maternal influenza vaccination and effect on influenza virus infection in young infants. Arch Pediatr Adolesc Med. 2011;165(2):104-11.

(98) Fell DB, Sprague AE, Liu N, et al. H1N1 influenza vaccination during pregnancy and fetal and neonatal outcomes. Am J Public Health. 2012;102(6):e33-40.

(99) Omer S, Goodman D, Steinhoff M, et al. Maternal influenza immunization and reduced likelihood of prematurity and small for gestational age births: a retrospective cohort study. PLoS Medicine. 2011;8(5):e1000441-.

(100) Steinhoff M, Omer S, Roy E, et al. Neonatal outcomes after influenza immunization during pregnancy: a randomized controlled trial. CMAJ. 2012;184(6):645-53.

(101) Dodds L, MacDonald N, Scott J, et al. The effect of influenza vaccine in pregnancy on adverse neonatal outcomes. J Obstetr Gynecol Canada. (In press).
(102) Steinhoff M, Omer S, Roy E, et al. Influenza immunization in pregnancy - Antibody responses in mothers and infants. N Engl J Med. 2010;362(17):1644-6.

(103) Omer SB, Bednarczyk R, Madhi SA, et al. Benefits to mother and child of influenza vaccination during pregnancy. Hum Vaccin Immunother. 2012;8(1):130-7.

(104) Tamma PD, Ault KA, del Rio C, et al. Safety of influenza vaccination during pregnancy. Am J Obstet Gynecol. 2009;201(6):547-52.

(105) MacDonald NE, Riley LE, Steinhoff MC. Influenza immunization in pregnancy. Obstet Gynecol. 2009;114(2 Pt 1):365-8.

(106) Moro PL, Broder K, Zheteyeva Y, et al. Adverse events in pregnant women following administration of trivalent inactivated influenza vaccine and live attenuated influenza vaccine in the Vaccine Adverse Event Reporting System, 1990-2009. Am J Obstet Gynecol. 2011;204(2):146.e1-7.

(107) Public Health Agency of Canada. Vaccine surveillance report-adverse events following immunization. 2010 Apr 27; Available at: http://www.phac-aspc.gc.ca/ alert-alerte/h1n1/vacc/addeve-eng.php.

(108) European Medicines Agency. Fifteenth Pandemic Pharmacovigilance update. 8 April 2010. Immunization. 2010 Apr 27; Available at: http://www. ema.europa.eu/pdfs/influenza/21323810en.pdf.

(109) Groom AV, Jim C, Laroque M, et al. Pandemic influenza preparedness and vulnerable populations in tribal communities. Am J Public Health. 2009;99(Suppl 2):S271-8.

(110) Samet JM, Key CR, Kutvirt DM, et al. Respiratory disease mortality in New Mexico's American Indians and Hispanics. Am J Public Health. 1980;70(5):492-7.

(111) La Ruche G, Tarantola A, Barboza P, et al. The 2009 pandemic $\mathrm{H} 1 \mathrm{~N} 1$ influenza and indigenous populations of the Americas and the Pacific. Euro Surveillance: Bulletin Europeen sur les Maladies Transmissibles = European Communicable Disease Bulletin. 2009; 14(42).

(112) Centers for Disease Control and Prevention. Deaths related to 2009 pandemic influenza $A$ (H1N1) among American Indian/Alaska Natives - 12 states, 2009. MMWR Morb Mortal Wkly Rep. 2009;58(48):1341-4. 
(113) International Center for Education Statistics. Individuals, families and chidlren in poverty. In: Status and trends in the education of American Indians and Alaska Natives. 2008; Available at: http://nces.ed.gov/ pubs2008/nativetrends/ind_1_6.asp.

(114) Canada. Royal Commission on Aboriginal peoples: People to people, nation to nation. Highlights from the report of the Royal Commission on Aboriginal peoples. 1996; Available at: http://www.ainc-inac.gc. ca/ap/pubs/rpt/rpt-eng.asp.

(115) Clark M, Riben P, Nowgesic E. The association of housing density, isolation and tuberculosis in Canadian First Nations communities. Int J Epidemiol. 2002;31(5):940-5.

(116) Zarychanski R, Stuart TL, Kumar A, et al. Correlates of severe disease in patients with 2009 pandemic influenza (H1N1) virus infection. CMAJ. 2010;182(3):257-64.

(117) Larcombe L, Rempel JD, Dembinski I, et al. Differential cytokine genotype frequencies among Canadian Aboriginal and Caucasian populations. Genes Immun. 2005;6(2):140-4.

(118) Carman WF, Elder AG, Wallace LA, et al. Effects of influenza vaccination of health-care workers on mortality of elderly people in long-term care: a randomised controlled trial. Lancet. 2000;355(9198):93-7.

(119) Hayward AC, Harling R, Wetten S, et al. Effectiveness of an influenza vaccine programme for care home staff to prevent death, morbidity, and health service use among residents: cluster randomised controlled trial. BMJ. 2006;333(7581):1241.

(120) Pearson ML. Bridges CB. Harper SA. Healthcare Infection Control Practices Advisory Committee (HICPAC). Advisory Committee on Immunization Practices (ACIP). Influenza vaccination of health-care personnel: recommendations of the Healthcare Infection Control Practices Advisory Committee (HICPAC) and the Advisory Committee on Immunization Practices (ACIP). MMWR Morb Mortal Wkly Rep. 2006;55(RR-2):1-16.

(121) Potter J, Stott DJ, Roberts MA, et al. Influenza vaccination of health care workers in long-term-care hospitals reduces the mortality of elderly patients. J Infect Dis. 1997;175(1):1-6.
(122) Lemaitre $M$, Meret T, Rothan-Tondeur $M$, et al. Effect of influenza vaccination of nursing home staff on mortality of residents: a cluster-randomized trial. J Am Geriatr Soc. 2009;57(9):1580-6.

(123) Saxen H, Virtanen M. Randomized, placebo-controlled double blind study on the efficacy of influenza immunization on absenteeism of health care workers. Pediatr Infect Dis J. 1999;18(9):779-83.

(124) Wilde JA, McMillan JA, Serwint J, et al. Effectiveness of influenza vaccine in health care professionals: a randomized trial. JAMA. 1999;281(10):908-13.

(125) Shugarman LR, Hales C, Setodji CM, et al. The influence of staff and resident immunization rates on influenza-like illness outbreaks in nursing homes. J Am Med Dir Assoc. 2006;7(9):562-7.

(126) Bridges CB, Lim W, Hu-Primmer J, et al. Risk of influenza $A(H 5 N 1)$ infection among poultry workers, Hong Kong, 1997-1998. J Infect Dis. 2002;185(8):1005-10.

(127) Puzelli S, Di Trani L, Fabiani C, et al. Serological analysis of serum samples from humans exposed to avian H7 influenza viruses in Italy between 1999 and 2003. J Infect Dis. 2005;192(8):1318-22.

(128) Tweed SA, Skowronski DM, David ST, et al. Human illness from avian influenza H7N3, British Columbia. Emerg Infect Dis. 2004;10(12):2196-9.

(129) Skowronski DM, Li Y, Tweed SA, et al. Protective measures and human antibody response during an avian influenza H7N3 outbreak in poultry in British Columbia, Canada. CMAJ. 2007;176(1):47-53.

(130) Department of Health UK. Flu vaccination for poultry workers. 2007; Available at: http://www.dh.gov.uk/en/ Publicationsandstatistics/Publications/ PublicationsPolicyAndGuidance/DH_063041.

(131) Gray GC, Trampel DW, Roth JA. Pandemic influenza planning: shouldn't swine and poultry workers be included?. Vaccine. 2007;25(22):4376-81.

(132) Committee to Advise on Tropical Medicine and Travel (CATMAT). National Advisory Committee on Immunization (NACl). Statement on travel, influenza, and prevention. Can Commun Dis Rep. 2005;31(ACS-2):1-8. 
(133) Van Damme P, Arnou R, Kafeja F, et al. Evaluation of non-inferiority of intradermal versus adjuvanted seasonal influenza vaccine using two serological techniques: a randomised comparative study. BMC Infect Dis. 2010;10:134.

(134) Thomas RE, Jefferson T, Lasserson TJ. Influenza vaccination for healthcare workers who work with the elderly. Cochrane Database Syst Rev. 2010(2):005187. 